Prepared as part of the U.S. Geological Survey Greater Everglades Priority Ecosystem Science Program Prepared in cooperation with the U.S. Army Corps of Engineers and Everglades National Park

\title{
Land-Margin Ecosystem Hydrologic Data for the Coastal Everglades, Florida, Water Years 1996-2012
}

Data Series 853 



\section{Land-Margin Ecosystem Hydrologic Data for the Coastal Everglades, Florida, Water Years 1996-2012}

By Gordon H. Anderson, Thomas J. Smith III, and Karen M. Balentine

Prepared as part of the

U.S. Geological Survey Greater Everglades Priority Ecosystem Science Program

Prepared in cooperation with the

U.S. Army Corps of Engineers and Everglades National Park

Data Series 853

U.S. Department of the Interior

U.S. Geological Survey 


\section{U.S. Department of the Interior \\ SALLY JEWELL, Secretary}

\section{U.S. Geological Survey \\ Suzette M. Kimball, Acting Director}

U.S. Geological Survey, Reston, Virginia: 2014

For more information on the USGS-the Federal source for science about the Earth, it's natural and living resources, natural hazards, and the environment-visit http://www.usgs.gov or call 1-888-ASK-USGS

For an overview of USGS information products, including maps, imagery, and publications, visit http://www.usgs.gov/pubprod

To order this and other USGS information products, visit http://store.usgs.gov

Any use of trade, firm, or product names is for descriptive purposes only and does not imply endorsement by the U.S. Government.

Although this information product, for the most part, is in the public domain, it also may contain copyrighted materials as noted in the text. Permission to reproduce copyrighted items must be secured from the copyright owner.

Suggested citation:

Anderson, G.H., Smith, T.J., III, and Balentine, K.M., 2014, Land-margin ecosystem hydrologic data for the coastal Everglades, Florida, water years 1996-2012: U.S. Geological Survey Data Series 853, 38 p., http://dx.doi.org/10.3133/ds853.

ISSN 2327-638X (online) 


\section{Contents}

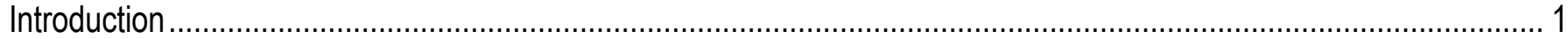

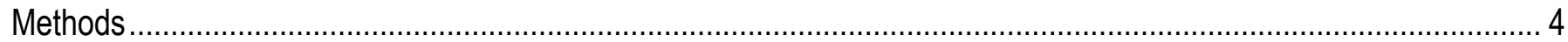

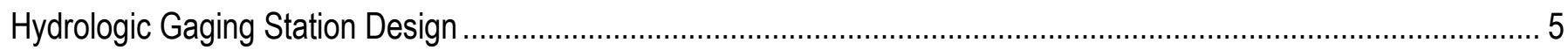

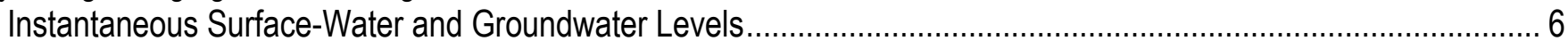

Instantaneous Surface-Water and Groundwater Specific Conductance and Salinity ......................................... 7

Instantaneous Surface-Water and Groundwater Temperature................................................................ 7

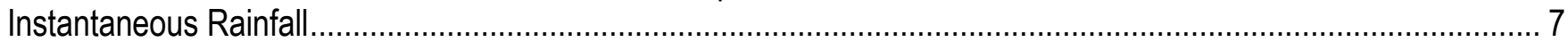

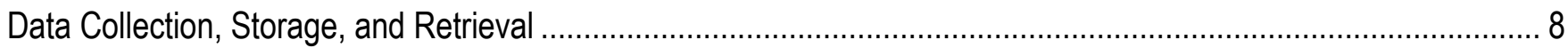

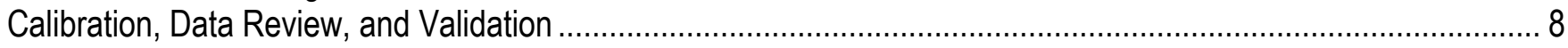

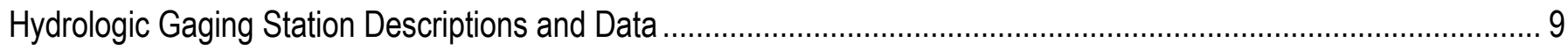

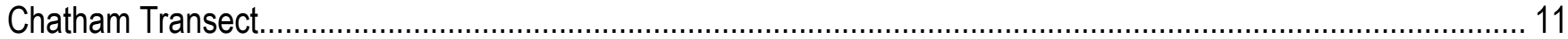

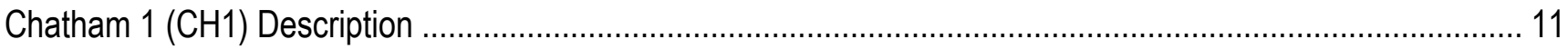

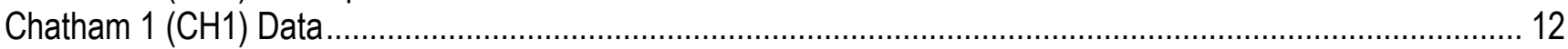

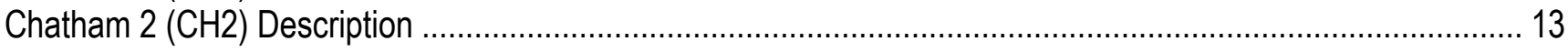

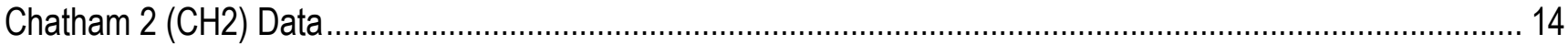

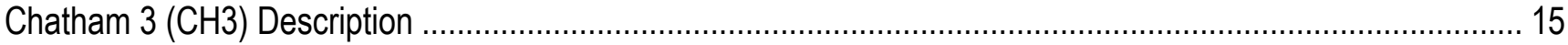

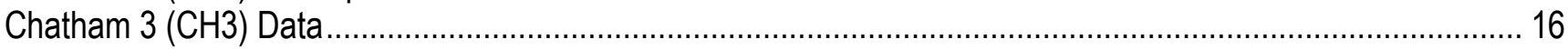

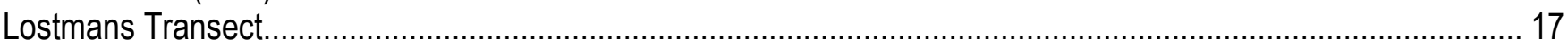

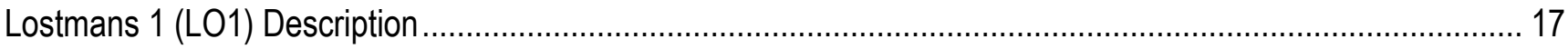

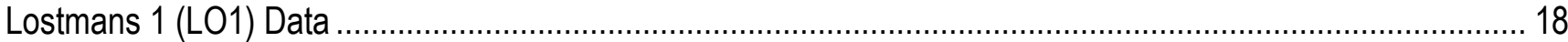

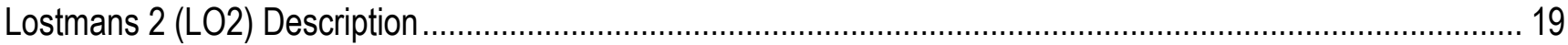

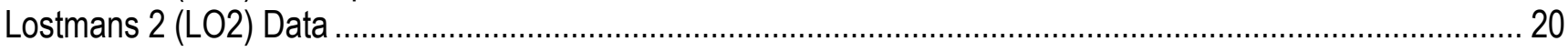

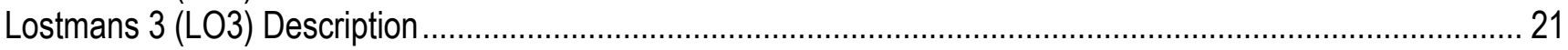

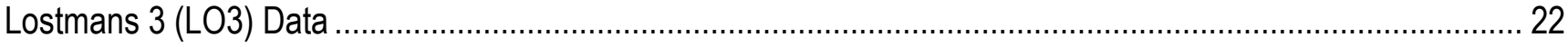

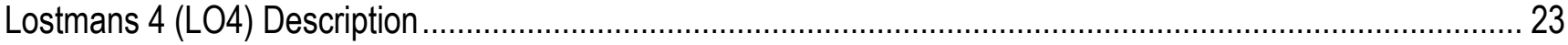

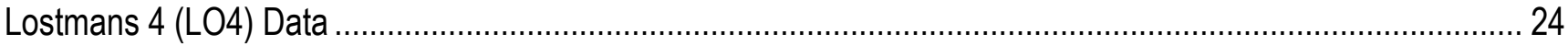

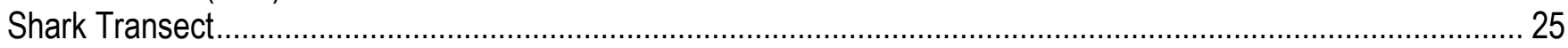

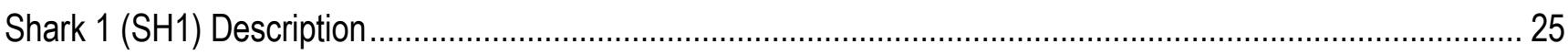

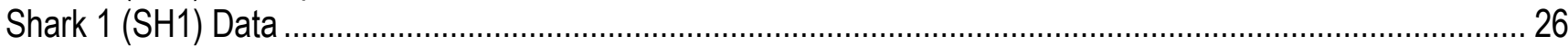

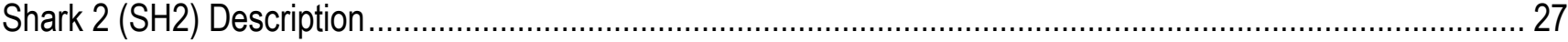

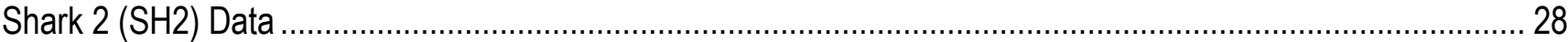

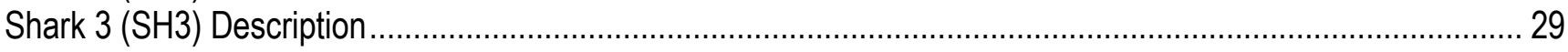

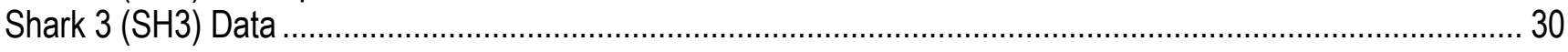

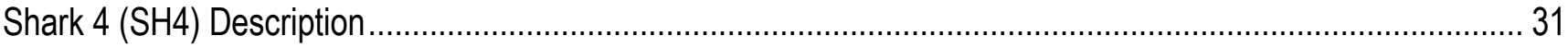

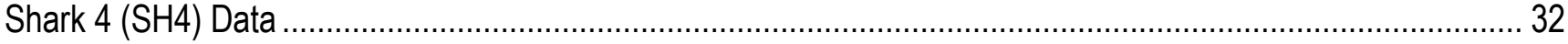

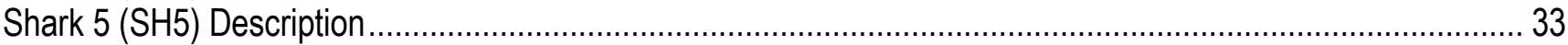

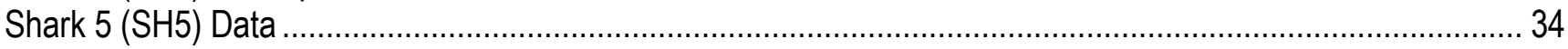

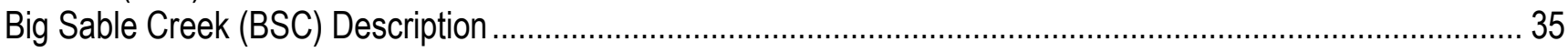

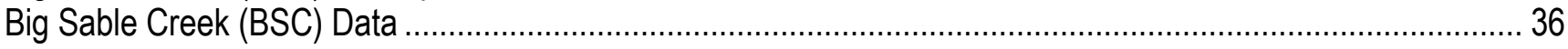

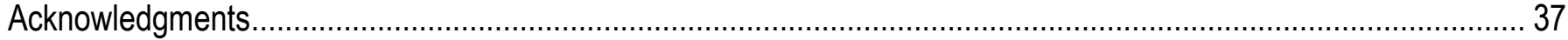

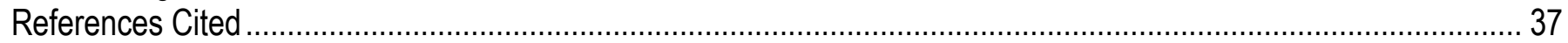




\section{Figures}

Figure 1. Map showing location of the 13 Land-Margin Ecosystem study hydrologic gaging stations, southwest coastal region of Everglades National Park, Florida 3

Figure 2. Schematic diagram showing typical paired surface-water and groundwater gaging station where water levels, salinities, temperatures, and rainfall were monitored 6

Figure 3. Example hydrologic gaging station $\mathrm{SH} 2$ chart of water parameter data during water years 1996-2012

\section{Tables}

Table 1. Project field equipment measurement acceptance range tolerance protocol 8

Table 2. Data review and quality assurance and quality control (QA/QC) adjustment methods used for Land-Margin Ecosystem hydrology data validation 


\section{Conversion Factors and Reference Datum}

\section{Conversion Factors}

Inch/Pound to SI

\begin{tabular}{lll}
\hline & Bultiply & \multicolumn{1}{c}{ To obtain } \\
\hline inch (in.) & Length & \\
inch (in.) & 2.54 & centimeter (cm) \\
foot (ft) & 25.4 & millimeter (mm) \\
\hline
\end{tabular}

SI to Inch/Pound

\begin{tabular}{lll}
\hline \multicolumn{1}{c}{ Multiply } & By & To obtain \\
\hline centimeter $(\mathrm{cm})$ & Length & \\
meter $(\mathrm{m})$ & 0.3937 & inch (in.) \\
meter $(\mathrm{m})$ & 3.281 & foot $(\mathrm{ft})$ \\
kilometer $(\mathrm{km})$ & 1.094 & yard (yd) \\
kilometer $(\mathrm{km})$ & 0.6214 & mile (mi) \\
\hline
\end{tabular}

Temperature in degrees Celsius $\left({ }^{\circ} \mathrm{C}\right)$ may be converted to degrees Fahrenheit $\left({ }^{\circ} \mathrm{F}\right)$ as follows: ${ }^{\circ} \mathrm{F}=\left(1.8 \times{ }^{\circ} \mathrm{C}\right)+32$.

Specific conductance is given in millisiemens per centimeter at 25 degrees Celsius $\left(\mathrm{mS} / \mathrm{cm}\right.$ at $\left.25^{\circ} \mathrm{C}\right)$.

Specific conductance, in millisiemens per centimeter may be converted to Practical Salinity Units (PSU) as follows: Salinity $=0.012+\left(-0.2174 \times((\mathrm{SC} / 1000) / 53.087)^{0.5}\right)+\left(25.3283 \times((\mathrm{SC} / 1000) / 53.087)^{1}\right)+\left(13.7714 \times((\mathrm{SC} / 1000) / 53.087){ }^{1.5}\right)$ $+\left(-6.4788 \times((\mathrm{SC} / 1000) / 53.087)^{2}\right)+\left(2.5842 \times((\mathrm{SC} / 1000) / 53.087)^{2.5}\right)$

$\mathrm{SC}$ is the specific conductivity in $\mathrm{mS} / \mathrm{cm}$. The salinity is represented in Practical Salinity Units (PSU), a unitless scale, approximately equivalent, but more consistent across the scale range than parts per thousand (PPT).

\section{Reference Datum}

Vertical coordinate information is referenced to the North American Vertical Datum of 1988 (NAVD 88). Horizontal coordinate information is referenced to the North American Datum of 1983 (NAD 83). 


\section{Acronyms and Abbreviations}

$\begin{array}{ll}\text { BRD } & \text { Biological Resources Division } \\ \text { ENP } & \text { Everglades National Park } \\ \text { FCE-LTER } & \text { Florida Coastal Everglades Long Term Ecological Research Program } \\ \text { GD } & \text { Geology Division } \\ \text { GOES } & \text { Geostationary Operational Environmental Satellites } \\ \text { GPS } & \text { Global Positioning System } \\ \text { MP } & \text { measurement point } \\ \text { NAD 83 } & \text { North American Datum of 1983 } \\ \text { NAVD 88 } & \text { North American Vertical Datum of 1988 } \\ \text { NESDIS } & \text { National Environmental Satellite Data and Information Service } \\ \text { NMD } & \text { National Mapping Department } \\ \text { NPS } & \text { National Park Service } \\ \text { NOAA } & \text { National Oceanic and Atmospheric Administration } \\ \text { OPUS } & \text { Online Positioning User Service } \\ \text { PV } & \text { Photovoltaic } \\ \text { POR } & \text { period of record } \\ \text { PSU } & \text { Practical Salinity Units } \\ \text { OA/OC } & \text { quality assurance and quality control } \\ \text { SDI } & \text { serial digital interface } \\ \text { SOFIA } & \text { South Florida Information Access } \\ \text { SOFL-GCC } & \text { South Florida Global Climate Change Project } \\ \text { UNESCO } & \text { United Nations Organization for Education, Science and Culture } \\ \text { WRD } & \text { Water Resources Division } \\ \text { WY } & \text { Water Year. Begins October 1 and ends on September 30. } \\ & \end{array}$




\title{
Land-Margin Ecosystem Hydrologic Data for the Coastal Everglades, Florida, Water Years 1996-2012
}

\author{
By Gordon H. Anderson, Thomas J. Smith III, and Karen M. Balentine
}

\section{Introduction}

Mangrove forests and salt marshes dominate the landscape of the coastal Everglades (Odum and McIvor, 1990). However, the ecological effects from potential sea-level rise and increased water flows from planned freshwater Everglades restoration on these coastal systems are poorly understood. The National Park Service (NPS) proposed the South Florida Global Climate Change Project (SOFL-GCC) in 1990 to evaluate climate change and the effect from rising sea levels on the coastal Everglades, particularly at the marsh/mangrove interface or ecotone (Soukup and others, 1990). A primary objective of SOFL-GCC project was to monitor and synthesize the hydrodynamics of the coastal Everglades from the upstream freshwater marsh to the downstream estuary mangrove. Two related hypotheses were set forward (Nuttle and Cosby, 1993):

1. There exists hydrologic conditions (tide, local rainfall, and upstream water deliveries), which characterize the location of the marsh/mangrove ecotone along the marine and terrestrial hydrologic gradient; and

2. The marsh/mangrove ecotone is sensitive to fluctuations in sea level and freshwater inflow from inland areas.

Hydrologic monitoring of the SOFL-GCC network began in 1995 after startup delays from Hurricane Andrew (August 1992) and organizational transfers from the NPS to the National Biological Survey (October 1993) and the merger with the U.S. Geological Survey (USGS) Biological Research Division in 1996 (Smith, 2004). As the SOFL-GCC project progressed, concern by environmental scientists and land managers over how the diversion of water from Everglades National Park would affect the restoration of the greater Everglades ecosystem. Everglades restoration scenarios were based on hydrodynamic models, none of which included the coastal zone (Fennema and others, 1994). Modeling efforts were expanded to include the Everglades coastal zone (Schaffranek and others, 2001) with SOFL-GCC hydrologic data assisting the ecological modeling needs. In 2002, as a response for a more interdisciplinary science approach to understanding the coastal Everglades ecological system, the SOFL-GCC hydrology project was integrated into the "Dynamics of Land-Margin Ecosystems: Historical Change, Hydrology, Vegetation, Sediment, and Climate" study (Smith and others, 2002). Data from the ongoing study has been useful in providing an empirical hydrologic baseline for the greater Everglades ecosystem restoration science and management needs. 
The hydrology network consisted of 13 hydrologic gaging stations installed in the southwestern coastal region of Everglades National Park along three transects: Shark River (Shark or SH) transect, Lostmans River (Lostmans or LO) transect, and Chatham River (Chatham or CH) transect (fig. 1). There were five paired surface-water/groundwater gaging stations on the Shark transect (SH1, SH2, $\mathrm{SH} 3, \mathrm{SH} 4$, and SH5) and one stage gaging station (BSC) in the Big Sable Creek; four paired surfacewater/groundwater gaging stations on the Lostmans transect (LO1, LO2, LO3, and LO4); and three paired surface-water/groundwater gaging stations on the Chatham transect $(\mathrm{CH} 1, \mathrm{CH} 2$, and $\mathrm{CH} 3)$. Both surface-water and groundwater levels, salinities, and temperatures were monitored at the paired gaging stations. Rainfall was recorded at marsh and open canopy gaging stations. This report details the study introduction, method, and description of data collected, which are accessible through the final instantaneous hydrologic dataset stored in the USGS South Florida Information Access (SOFIA) South Florida Hydrology Database website, http://sofia.usgs.gov/exchange/sfl_hydro_data/location.html\#brdlandmargin. 


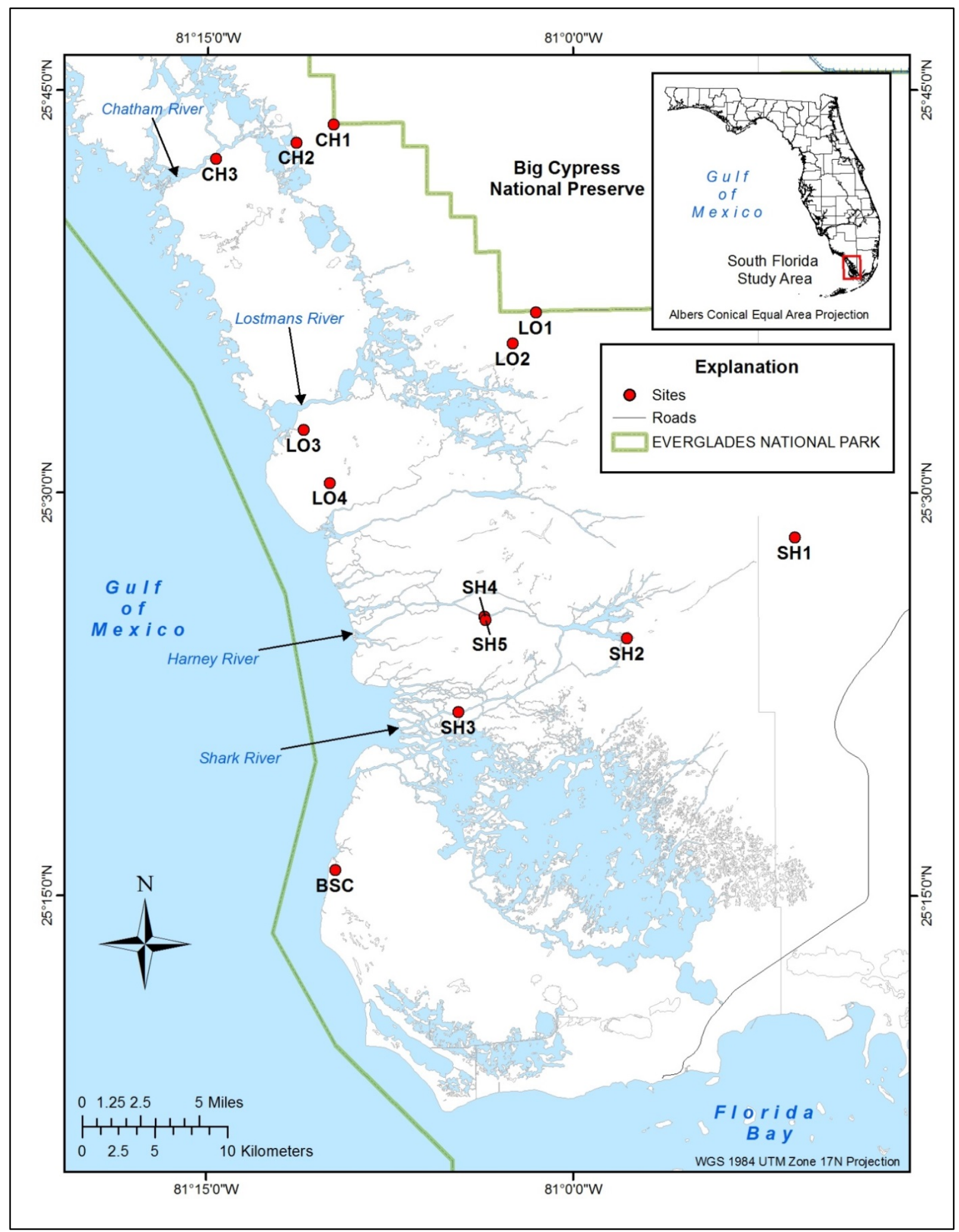

Figure 1. Map showing location of the 13 Land-Margin Ecosystem study hydrologic gaging stations, southwest coastal region of Everglades National Park, Florida (Graphic credit: Richard Westcott). 


\section{Methods}

The Land-Margin Ecosystem hydrology network consists of three replicate transects (Shark, Lostmans, and Chatham) used to test first SOFL-GCC hypothesis: There exists hydrologic conditions; tide, local rainfall, and upstream water deliveries that characterize the location of the marsh/mangrove ecotone along the marine - terrestrial hydrologic gradient. Each transect consisted of at least three gaging stations. An upstream freshwater marsh gaging station, a marsh/mangrove ecotone gaging station, and a downstream estuary mangrove gaging station. Although the river transects differed in reach, ecotone, and freshwater inflow regimes, they collectively represent the principal southwestern coastal drainages within Everglades National Park. Gaging station names were denoted with a two character transect/river abbreviation $(\mathrm{SH}, \mathrm{LO}, \mathrm{CH})$ and the numbers: 1, 2, or 3. Each upstream transect gaging station ( $\mathrm{SH} 1, \mathrm{LO} 1$, and $\mathrm{CH} 1)$ was located in a freshwater marsh or prairie, typically dominated by sawgrass (Cladium jamaicense) and spikerush (Eleocharis cellulosa) with no perceptual tidal influence in the surface water. Each middle transect gaging station (SH2, LO2, and $\mathrm{CH} 2)$ was located near the marsh/mangrove interface or ecotone. This ectone habitat consisted of mixed mangrove-red mangrove (Rhizophora mangle), black mangrove (Avicennia germinans), white mangrove (Laguncularia racemosa), buttonwood (Conocarpus erectus); and coastal marsh—rush (Juncus sp.) and sawgrass (Cladium jamaicense). Surface water and groundwater at the ecotone "2" gaging stations were characterized by an attenuated tidal signal and a large seasonal hydrodynamic fluctuation in salinity. The downstream estuary transect gaging stations ( $\mathrm{SH} 3, \mathrm{LO} 3, \mathrm{CH} 3)$ were located within mature stands of red, black, and white mangrove. The surface water at the "3" gaging stations had a pronounced diurnal tidal signal and salinities within the polyhaline zone (30 \pm 18 Practical Salinity Units [PSU]).

In addition to the three primary transect gaging stations, the Shark transect had three supplemental gaging stations and the Lostmans transect had one supplemental gaging station. The Shark transect had two supplemental gaging stations (SH4 and SH5) near the Harney River. Gaging station SH4 was in a fringe mangrove forest on the southern bank of the Harney River and gaging station SH5 was in a coastal marsh $300 \mathrm{~m}$ south of the river. These two gaging stations represent a scaled-down or mesoscale version of the primary marsh/mangrove transect. The third Shark transect supplemental gaging station, Big Sable Creek (BSC) gaging station, was built in 2001 in the southern branch of the Big Sable Creek near the Gulf of Mexico. Gaging station BSC monitored surface-water parameters and primarily was used to provide supportive hydrologic data to evaluate sediment change dynamics and mangrove ecology (Smith and Cahoon, 2003). Lostmans transect supplemental gaging station (LO4) was installed in coastal marsh on Key McLaughin to assist in characterizing the interior coastal marsh hydrodynamics (fig. 1). 


\section{Hydrologic Gaging Station Design}

The Land-Margin Ecosystem hydrologic gaging stations consisted of a platform supporting an instrument enclosure, a stilling well for measuring surface water height, and a piezometer for measuring hydraulic head (groundwater) in the semi-confined, surficial aquifer (fig. 2). The surface-water stilling well was set within a soil (peat or marl) profile and cased with perforated 30-cm diameter polyvinyl chloride (PVC) pipe. The shallow groundwater well was drilled through the full depth of soil profile and 1-2 $\mathrm{m}$ into the limestone surficial aquifer. The borehole was cased with $10-\mathrm{cm}$ diameter PVC pipe and a screened interval for the bottom $150 \mathrm{~cm}$. The screened interval was sealed at the sediment/limestone interface with a well collar and bentonite clay to prevent vertical water mixing. Exact dimensions of each piezometer are listed in section, "Hydrologic Gaging Station Descriptions and Data."

The gaging stations recorded instantaneous measurements of surface-water and groundwater levels (in decimal feet), specific conductance (in millesiemens per centimeter at 25 degrees Celsius), temperature (in degrees Celsius), and rainfall (in inches). Surface-water level was measured using a float and pulley in a stilling well and groundwater level was monitored with a potentiometric sensor (fig. 2). All water-level measurements were referenced to the North American Vertical Datum of 1988 (NAVD 88), established with high precision vertical global positioning surveying methods (Shupe and others, unpub. data, 2007).

Rainfall collectors were installed across the coastal region to better characterize local spatial rainfall distribution. Tipping bucket rainfall collectors were installed at open canopy gaging station sites: SH1, SH2, SH5, BSC, LO1, LO2, LO4, CH1, and CH2. All hydrologic data were collected and stored with a data logger and transmitted daily using (Geostationary Operational Environmental Satellites (GOES) or radio telemetry to NPS database DataForEver, locally maintained by Everglades National Park. The NPS database was cooperatively provided to the USGS for local study data access, storage, and review. Final validated study data described in this report are publically accessible through the USGS SOFIA South Florida Hydrology Database website, http://sofia.usgs.gov/exchange/sfl_hydro_data/location.html\#brdlandmargin. 


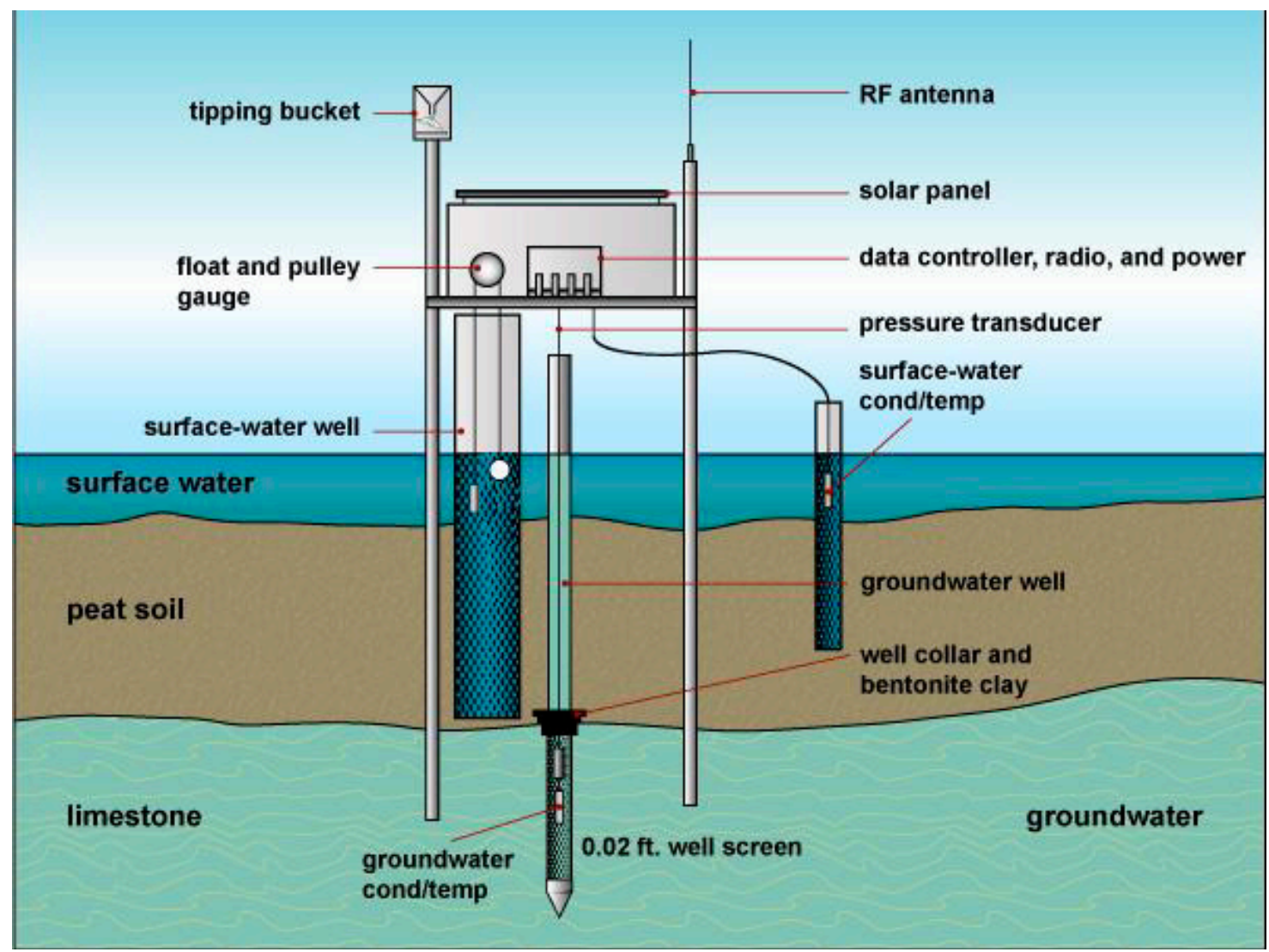

Figure 2. Schematic diagram showing typical paired surface-water and groundwater gaging station where water levels, salinities, temperatures, and rainfall were monitored.

\section{Instantaneous Surface-Water and Groundwater Levels}

Surface-water and groundwater levels were initially recorded as averaged hourly values. Waterlevel monitoring was changed to a 15-minute instantaneous sampling interval at lower estuary gaging stations in 2003 to better characterize tidal influence. Freshwater marsh water levels were changed from hourly averaged values to 15-minute instantaneous measurements after 2006. Surface-water level accuracy and measurement reliability was improved in 2006 when 10-tip float/pulley potentiometers were replaced with float/pulley using serial digital interface (SDI) shaft encoders. Groundwater-level samples were measured with passive resistance tape sensors until 2003 and then replaced with vented pressure transducer sensors, which improved monitoring accuracy. All water levels were measured in decimal feet and referenced to the NAVD 88 datum. 


\section{Instantaneous Surface-Water and Groundwater Specific Conductance and Salinity}

Surface-water and groundwater specific conductance (corrected to $25^{\circ} \mathrm{C}$ ) was initially measured with a single toroidal induction conductivity sensor inside of a measurement chamber. An hourly surface-water and groundwater sample was pumped into a chamber through water pump/manifold/ tubing system for measurement. However, because of excessive power demand failure of the water pump, and manifold and tubing fouling, this method of sampling was discontinued in 2001 and replaced with in situ sampling. Only one operational sensor per gaging station was available to measure either surface-water or groundwater specific conductance until 2003, because of funding limitations. Typically, specific conductance sampling of surface water was preferentially selected during this period. In 2003, the toroidal sensors were replaced with 2-electrode conductivity/temperature sensors (sondes) to improve accuracy and reduce measurement drift, and additional sensors were obtained to allow monitoring of both surface water and groundwater. Additionally, the sampling interval frequency was increased to $15 \mathrm{~min}$ to coincide with the water-level sampling. Specific conductance field measurements were measured in millisiemens per centimeter and normalized to $25^{\circ} \mathrm{C}\left(\mathrm{mS} / \mathrm{cm}\right.$ at $\left.25^{\circ} \mathrm{C}\right)$. Field recorded specific conductance values were converted and stored as PSU within the DataForEver database using the 1985 United Nations Organization for Education, Science and Culture (UNESCO) standard formula (United Nations Organization for Education, Science and Culture, 1985).

\section{Instantaneous Surface-Water and Groundwater Temperature}

In 1999, thermistor temperature probes were added for sampling water temperature. The temperature thermistor was used with a toroidal specific conductivity sensor for hourly water sampling using the pump/manifold/tubing system until the pump system was discontinued in 2001. After 2001, surface-water temperature was measured in situ. In 2003, the thermistor sensors were replaced with single 2-electrode conductivity/temperature sondes for monitoring surface-water and groundwater temperature at the gaging station. Water temperature sampling was changed from an hourly to a 15minute interval during 2003-06 to coincide with the water-level and specific conductance sampling schedule. Water temperature data were recorded in degrees Celsius.

\section{Instantaneous Rainfall}

Instantaneous rainfall was measured only at gaging station locations free of tree canopy interference. Beginning in 1997, rainfall was measured at gaging stations LO4 and H2. Additional rain tipping buckets were installed at gaging stations SH1, SH2, SH5, LO1, LO2, and BSC during 2000-01. Rainfall was measured with a pulse-funnel style tipping bucket (0.01 in. per tip). Rainfall measurements were recorded in decimal inches and stored as hourly summed data. 


\section{Data Collection, Storage, and Retrieval}

Instantaneous water data were recorded and stored at each gaging station in a data logger/controller powered with a solar photovoltaic (PV) 12-volt battery system. Initially, logger-stored data were transferred daily to the Everglades National Park computer database DataForEver using a local radio frequency (RF) network. After 2006, GOES satellite transmitters replaced the RF network and data were sent directly from the logger to GOES satellite, operated by the National Oceanic and Atmospheric Administration's National Environmental Satellite Data and Information Service (NESDIS). Incoming data, transmitted hourly to NESDIS, was downloaded through the Internet to the NPS database on a daily basis. These data from the Land-Margin Ecosystem Hydrology study were reviewed, and validated at the project level. (Anderson and Balentine, 2011. Unpublished report "Standard operating procedures for USGS-BRD Land-Margin Ecosystem study hydrological instrument calibration and quality control of physical water parameter data collected in Everglades National Park.")

\section{Calibration, Data Review, and Validation}

Quality Assurance and Quality Control (QA/QC) of the hydrologic data were fundamental to the USGS Land-Margin Ecosystem study. During field visits, sensors were cleaned and calibrated, and data were manually collected to fill in satellite transmission data gaps (table 1). Repair or replacement of faulty equipment was done as promptly as feasible. Gaging stations on the primary transects (Shark and Lostmans) were scheduled for routine field visits every 30-60 days; whereas, secondary network transect gaging stations $(\mathrm{CH} 1, \mathrm{CH} 2, \mathrm{LO} 4)$ were scheduled for visits every 90-120 days. Site visits were made more frequently in response to observed data irregularities, or evidence of equipment failure or data loss. Monitoring equipment was calibrated or replaced (if inoperable) when field measured values exceeded acceptable study tolerance ranges. Instantaneous data were transferred to the USGS-operated SOFIA South Florida Hydrology database after project data were locally reviewed for QA/QC and validation (table 2). It should be noted that these data were not processed by USGS protocols and should be considered "furnished data" (Larsen, 2008).

Table 1. Project field equipment measurement acceptance range tolerance protocol.

\begin{tabular}{|l|l|}
\hline \multicolumn{1}{|c|}{ Monitoring equipment type } & \multicolumn{1}{|c|}{$\begin{array}{c}\text { Reset or replace sensor when difference between } \\
\text { recorded value and calibration measurement is greater } \\
\text { than: }\end{array}$} \\
\hline $\begin{array}{l}\text { All water level sensors (potentiometer/shaft } \\
\text { encoder/pressure transducer) }\end{array}$ & Greater than 0.015 feet from field measurement \\
\hline $\begin{array}{l}\text { All specific conductivity sensors (electrode } \\
\text { and toroidal probes) }\end{array}$ & $\begin{array}{l}\text { Greater than 5 percent of the measurement range or } \\
1 \text { millisiemens (whichever is less) }\end{array}$ \\
\hline All temperature sensors & $\begin{array}{l}\text { Greater than } 1.50 \text { degrees Celsius. Note: Temperature } \\
\text { sensors are typically nonadjustable. Replace or factory } \\
\text { recalibration required }\end{array}$ \\
\hline Tipping bucket rain collector & $\begin{array}{l}\text { Greater than 5percent drip bottle field test calibrate } \\
\text { every } 6 \text { months (typically in May and December) }\end{array}$ \\
\hline
\end{tabular}


Table 2. Data review and quality assurance and quality control (QA/QC) adjustment methods used for Land-Margin Ecosystem hydrology data validation.

\begin{tabular}{|c|c|}
\hline Data QA/QC adjustment methods & Description of data QA/QC adjustment methods \\
\hline Graph & $\begin{array}{l}\text { First review of data. Look for obvious and erroneous spikes, flat } \\
\text { lines, outliers or missing data from transmission gap. Delete bad } \\
\text { records and manually upload data from field visits into database to } \\
\text { backfill data record. }\end{array}$ \\
\hline Visual & $\begin{array}{l}\text { Primarily useful for short duration time-series data gaps, that can be } \\
\text { accurately estimated from local or ancillary knowledge of } \\
\text { mechanical, electrical, or environmental factors. }\end{array}$ \\
\hline Linear interpolation & $\begin{array}{l}\text { When sensor values drift or deviate from acceptable tolerances } \\
\text { (table x), the linear interpolation method can be used to adjusts } \\
\text { sensor drift between two field sensor calibrations. The data record } \\
\text { time series slope is adjusted from the two field calibrated } \\
\text { measurements. This method of adjustment is limited to slight- } \\
\text { modest sensor drift, not acute and dramatic changes of slope or } \\
\text { magnitude that is, tape slip, sensor out of water). }\end{array}$ \\
\hline Constant offset & $\begin{array}{l}\text { Constant offset adjustment of data. Change in reference datum such } \\
\text { as, local datum to North American Vertical Datum of } 1988 \text { new } \\
\text { platform height or field adjusted survey, fixed coefficient change } \\
\text { (water density) are several examples of constant offset data } \\
\text { adjustment. }\end{array}$ \\
\hline Block record removal & $\begin{array}{l}\text { Missing or erroneous data records can result from dry wells, power } \\
\text { failure, faulty sensors, and data logger overflow, or from numerous } \\
\text { mechanical, electrical, human, or environment factors. Because of a } \\
\text { myriad of unknown conditions and variables, these data are never } \\
\text { estimated and are marked as absent or "null." }\end{array}$ \\
\hline
\end{tabular}

\section{Hydrologic Gaging Station Descriptions and Data}

The gaging station descriptions summarize the history and development of each gaging station; including gaging station name, location, well development, gaging station design, equipment, and vertical control reference. Figure 3 shows an example chart (SH2) of water parameter data from water years 1996-2012. Data from each gaging station is accessible through the SOFIA South Florida Hydrology Database website, http://sofia.usgs.gov/exchange/sfl_hydro_data/location.html\#brdlandmargin. 

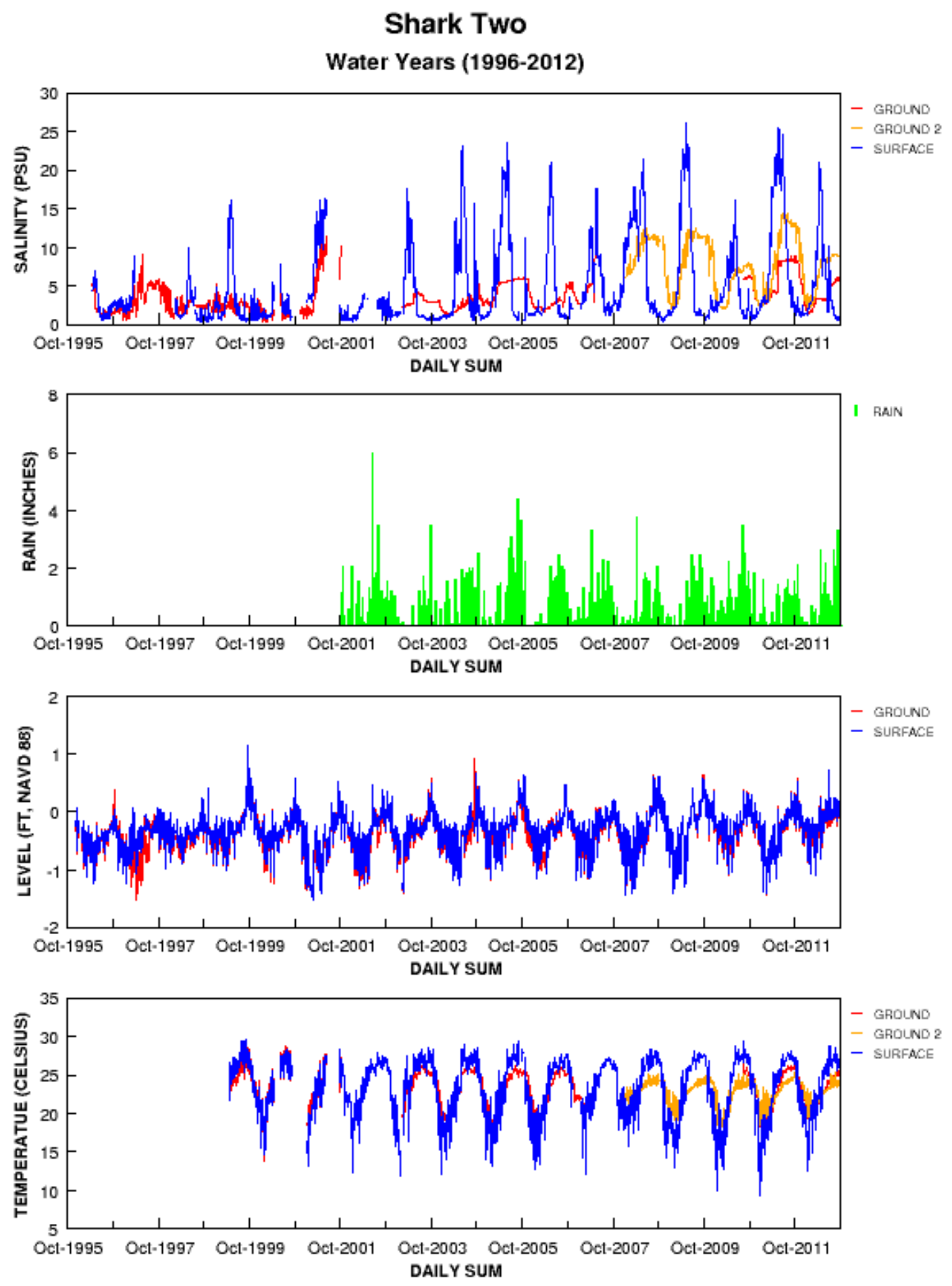

Figure 3. Example hydrologic gaging station SH2 chart of water parameter data during water years 1996-2012. 


\section{Chatham Transect}

Chatham 1 (CH1) Description

Latitude: $25^{\circ} 43^{\prime} 44.03^{\prime \prime}$

Longitude: $\quad-81^{\circ} 09^{\prime} 51.44^{\prime \prime}$

UTM Easting Zone 17N: 483520.79

UTM Northing Zone 17N: 2845671.74

Gaging station Operational: January 1, 1996

Gaging station Status: Transferred to USGS Coastal Gradients Study on October 1, 2012

(renamed MO-216).

Gaging Station Location

Gaging station is located in a freshwater sawgrass prairie within Everglades National Park, $9 \mathrm{~km}$ southwest of NPS gaging station 'Roberts Lake', Big Cypress National Preserve. Accessed by airboat or helicopter.

History

The gaging station consists of two monitoring wells: surface water stilling well consisting of a 12-in. diameter PVC pipe set in shallow marl sediment (1 ft) to bedrock and groundwater well in a drilled bore hole (10 ft) into the limestone aquifer and cased with a 3 -in. PVC riser and $5 \mathrm{ft}$ screened interval on the bottom (0.02-in. well screen). Groundwater well was drilled on April 28, 1995, and gaging station was operational by January 1, 1996. Gaging station platform top was replaced on September 15, 2010, with no change in platform reference height with new monitoring equipment installed. Gaging station was transferred to USGS-WRD October 1, 2012, and renamed MO-216.

Gaging Station Design

Data logger, battery, and monitoring instruments are housed within an aluminum housing box on top of a wooden platform supported by four steel pipes. Surface-water and groundwater levels; surface-water and groundwater specific conductance; surface-water and groundwater temperature; and rainfall were monitored. Gaging station was operated by a PV power system. Radio telemetry was initially used and later GOES satellite transmission was used for daily data transfer.

$\underline{\text { References and Benchmarks }}$

Measurement point (MP) is the aluminum base of the instrument housing on the gaging station platform. A local benchmark is 3-in. aluminum cap set on a 5/8-in. rebar driven to refusal within a 3-in. PVC pipe filled with concrete approximately $20 \mathrm{ft}$ southeast of gaging station. Vertical (NAVD 88) and horizontal (NAD 83) references were determined by precise differential GPS survey by USGS in 2000 and 2001 (OPUS solution, GEIOD 99).

\begin{tabular}{lccccc}
\hline CH1 & Aluminum platform base & 3-in. aluminum cap & \multicolumn{3}{c}{ Ground surface (Marsh) } \\
\hline Reference elevations & Measurement point & Local benchmark & Average & Maximum & Minimum \\
(ft, NAVD 88) & 3.16 & 1.43 & -0.14 & 0.01 & -0.52 \\
\hline
\end{tabular}


Chatham 1 (CH1) Data

CH1 gaging station was operated for 16.75 years (January 1996-January 2012). Hourly surface-water and groundwater monitoring record began in 1996 for water levels and in 1998 for surface-water salinity. Water temperatures and groundwater salinity monitoring started in 2000 and in 2001 for rainfall. All water parameters, except rainfall, time-series measurement interval were changed to $15 \mathrm{~min}$ in 2008.

\begin{tabular}{|c|c|c|c|c|c|c|c|}
\hline \multirow{2}{*}{$\begin{array}{l}\text { CH1 } \\
\text { Period of record (hourly) }\end{array}$} & \multicolumn{3}{|c|}{ Surface water } & \multicolumn{3}{|c|}{ Groundwater } & \multirow[t]{2}{*}{ Rainfall } \\
\hline & Level & Salinity & Temperature & Level & Salinity & Temperature & \\
\hline Begin & 1/1/1996 & $10 / 16 / 1998$ & $10 / 12 / 2000$ & $1 / 1 / 1996$ & $10 / 12 / 2000$ & $10 / 12 / 2000$ & $5 / 7 / 2001$ \\
\hline End & $5 / 27 / 2008$ & $5 / 27 / 2008$ & $5 / 27 / 2008$ & $5 / 27 / 2008$ & $5 / 27 / 2008$ & $5 / 27 / 2008$ & $9 / 30 / 2012$ \\
\hline \multicolumn{8}{|l|}{ Period of record (15 min) } \\
\hline Begin & $5 / 28 / 2008$ & $5 / 28 / 2008$ & $5 / 28 / 2008$ & $5 / 28 / 2008$ & $5 / 28 / 2008$ & $5 / 28 / 2008$ & \\
\hline End & $9 / 30 / 2012$ & $9 / 30 / 2012$ & $9 / 30 / 2012$ & $9 / 30 / 2012$ & $9 / 30 / 2012$ & $9 / 30 / 2012$ & \\
\hline $\begin{array}{l}\text { Successful collection of } \\
\text { data (\% of days during } \\
\text { POR). }\end{array}$ & 94 & 89 & 95 & 96 & 83 & 90 & 77 \\
\hline
\end{tabular}

CH1 data quality was good. Rainfall data collection was diminished due to equipment failure. Water pump sampling was not used for salinity measurements. Field visits were irregular after 2006, due to curtailed funding. CH1 period of record for water levels (feet), salinity (Practical Salinity Units), temperature (degrees Celsius), and rainfall (inches), Everglades National Park, Florida. CH1 instantaneous water data are available at South Florida Hydrologic Database, http://sofia.usgs.gov/exchange/sfl_hydro_data/location.html\#brdlandmargin. 
Chatham 2 (CH2) Description

Latitude: $\quad 25^{\circ} 43^{\prime} 03.74$ '

Longitude: $\quad-81^{\circ} 11^{\prime} 22.66^{\prime \prime}$

UTM Easting Zone 17N: 480977.35

UTM Northing Zone 17N: 2844435.78

Gaging station Operational: January 27, 1996

Gaging station Status: Discontinued May 8, 2007

Gaging Station Location

Gaging station is located in coastal scrub mangrove marsh, $0.3 \mathrm{~km}$ east of Chevelier Bay, Everglades

National Park. Accessed by Helicopter.

History

The gaging station consists of two monitoring wells: surface water stilling well consists of a 12 -in. diameter PVC pipe set into peat sediment (6 ft) to bedrock and groundwater well in a drilled bore hole (14 ft) into the limestone aquifer and cased with a 3-in. PVC riser and 5-ft screened interval on the bottom (0.02-in. well screen). Groundwater well was drilled on May 24, 1994, and gaging station was operational by January 27, 1996. Gaging station was discontinued on May 8, 2007.

\section{Gaging Station Design}

Data logger, battery, and monitoring instruments are housed within an aluminum housing box on top of a wooden platform supported by four steel pipes. Surface-water and groundwater levels, surface-water and groundwater specific conductance; surface-water and groundwater temperature; and rainfall were monitored. Gaging station was operated by a photovoltaic power system. Radio telemetry was initially used and later GOES satellite transmission was used for daily data transfer.

$\underline{\text { References and Benchmarks }}$

Measurement point (MP) is the aluminum base of the instrument housing on the gaging station platform. A local benchmark is a 3-in. aluminum cap set on a 5/8-in. rebar driven to refusal within a 3in. PVC pipe filled with concrete approximately $5 \mathrm{ft}$ west of gaging station. Vertical (NAVD 88) and horizontal (NAD 83) references were determined by precise differential GPS survey by USGS in 2001 and 2002 (OPUS solution, GEOID 99).

\begin{tabular}{lccccc}
\hline $\mathrm{CH} 2$ & Aluminum platform base & 3-in. aluminum cap & \multicolumn{3}{c}{ Ground surface (Marsh) } \\
\hline Reference elevations & Measurement Point & Local Benchmark & Average & Maximum & Minimum \\
(ft, NAVD 88) & 2.47 & -0.15 & -0.55 & -0.44 & -0.70 \\
\hline
\end{tabular}


Chatham 2 (CH2) Data

CH2 gaging station was operated for 10.75 years (January 1996-September 2006). Overall, data quality was good. Hourly surface-water and groundwater monitoring record began in 1996 for water levels and in 1998 for surface water salinity and rainfall. Water temperatures and groundwater salinity monitoring begin in 2000 .

\begin{tabular}{lccccccc}
\hline CH2 & \multicolumn{3}{c}{ Surface water } & \multicolumn{3}{c}{ Groundwater } & Rainfall \\
\hline Period of record (hourly) & Level & Salinity & Temperature & Level & Salinity & Temperature \\
Begin & $1 / 27 / 1996$ & $10 / 16 / 1998$ & $6 / 18 / 2001$ & $1 / 27 / 1996$ & $12 / 21 / 2000$ & $12 / 21 / 2000$ & $7 / 24 / 1998$ \\
End & $5 / 16 / 2006$ & $7 / 30 / 2004$ & $7 / 30 / 2004$ & $9 / 10 / 2006$ & $9 / 9 / 2006$ & $9 / 9 / 2006$ & $9 / 9 / 2006$ \\
$\begin{array}{l}\text { Successful collection of } \\
\text { data (\% of days during }\end{array}$ & 81 & 46 & 60 & 86 & 89 & 90 & 84 \\
POR). & & & & & & \\
\hline
\end{tabular}

Overall, $\mathrm{CH} 2$ data quality was good. Surface water salinity and temperature data were limited due to equipment failure. Data quality, especially salinity, was affected by sensor failure from irregular field visits, due to difficulty of remote gaging station access. Water pump sampling was not used for salinity measurements. All monitoring ended by September 2006, due to curtailed funding. $\mathrm{CH} 2$ instantaneous water data are available at South Florida Hydrologic Database, http://sofia.usgs.gov/exchange/sfl_hydro_data/location.html\#brdlandmargin. 
Chatham 3 (CH3) Description

Latitude: $\quad 25^{\circ} 42^{\prime} 26.44^{\prime \prime}$

Longitude: $\quad-81^{\circ} 14^{\prime} 40.41^{\prime \prime}$

UTM Easting Zone 17N: 475464.78

UTM Northing Zone 17N: 2843297.45

Gaging station Operational: January 27, 1996

Gaging station Status: Discontinued October 2, 2012

Gaging Station Location

Gaging station located in a riverine mangrove forest near Chatham River, $0.2 \mathrm{~km}$ southeast of Watson Place Campground, Everglades National Park. Accessed by boat.

History

The gaging station consists of two monitoring wells: surface water stilling well is a 12-in. diameter PVC pipe set in peat sediment $(7 \mathrm{ft})$ to bedrock and groundwater well in a drilled bore hole (16 ft) into the limestone aquifer and cased with a 3-in. PVC riser and 5-ft screened interval on the bottom (0.02-in. well screen). Groundwater well was drilled on May 20,1994, and gaging station was operational by January 27, 1996. Gaging station was rebuilt July 2, 2003, with wooden frame $2.56 \mathrm{ft}$ higher than previous monitoring platform with new monitoring equipment installed. Gaging station was discontinued October 2, 2012.

Gaging Station Design

Data logger, battery, and monitoring instruments are housed within an aluminum housing box on top of a wooden platform supported by four steel pipes. Surface-water and groundwater levels, surface-water and groundwater specific conductance; surface-water and groundwater temperature were monitored. Gaging station was operated by a photovoltaic power system. Radio telemetry was initially used and later GOES satellite transmission was used for daily data transfer.

$\underline{\text { References and Benchmarks }}$

Measurement point (MP) is the aluminum base of the instrument housing on the gaging station platform. A local benchmark is a 3-in. aluminum cap set on a 5/8-in. rebar driven to refusal within a 3in. PVC pipe filled with concrete approximately $10 \mathrm{ft}$ east of gaging station. Vertical (NAVD 88) and horizontal (NAD 83) references were determined by precise differential GPS survey by USGS-NMD and USGS-GD in 2007 (OPUS solution, GEOID 99).

\begin{tabular}{lccccc}
\hline CH3 & Aluminum platform base & 3-in. Aluminum cap & \multicolumn{3}{c}{ Ground surface (Mangrove) } \\
\hline Reference elevations & Measurement point & Local benchmark & Average & Maximum & Minimum \\
(ft, NAVD 88) & 5.62 & 2.09 & 0.29 & 0.38 & 0.22 \\
\hline
\end{tabular}


Chatham $3(\mathrm{CH} 3)$ Data

CH3 gaging station was operated for 16.75 years (January 1996-September 2012). Overall, data quality was fair, because of the impact the harsh coastal saline environment and dense tree canopy had on sensor reliability, PV power and data transmission. Hourly surface-water and groundwater monitoring record began in 1996 for water levels and salinities. Groundwater temperature monitoring began in 2000 and in 2002 for surface water. Water level time-series measurement interval was changed to $15 \mathrm{~min}$ in 2003 and in 2007 for salinity and temperature measurements.

\begin{tabular}{lcccccc}
\hline CH3 & \multicolumn{3}{c}{ Surface water } & \multicolumn{3}{c}{ Groundwater } \\
\hline Period of record (hourly) & Level & Salinity & Temperature & Level & Salinity & Temperature \\
Begin & $1 / 27 / 1996$ & $10 / 11 / 1996$ & $1 / 16 / 2002$ & $1 / 27 / 1996$ & $10 / 11 / 1996$ & $10 / 25 / 2000$ \\
End & $8 / 14 / 2003$ & $1 / 10 / 2007$ & $1 / 10 / 2007$ & $8 / 14 / 2003$ & $1 / 10 / 2007$ & $1 / 10 / 2007$ \\
Period of record (15 $\mathbf{m i n})$ & & & & & & \\
Begin & $8 / 15 / 2003$ & $1 / 11 / 2007$ & $1 / 11 / 2007$ & $8 / 15 / 2003$ & $1 / 11 / 2007$ & $1 / 11 / 2007$ \\
End & $9 / 30 / 2012$ & $9 / 30 / 2012$ & $9 / 30 / 2012$ & $12 / 23 / 2011$ & $9 / 30 / 2012$ & $9 / 30 / 2012$ \\
Successful collection of data & 72 & 54 & 56 & 68 & 46 & 63 \\
(\% of days during POR). & 72 & & & & & \\
\hline
\end{tabular}

Overall, $\mathrm{CH} 3$ data quality was fair, due to harsh site conditions and there was substantial data loss, especially salinity and temperature data, due to equipment failure. Water pump sampling for surface water salinity was used for 2 years with modest success, but was discontinued because of excessive maintenance and equipment failure. New platform was rebuilt and new monitoring equipment installed in August 2003. Data loss occurred from Hurricane Katrina (August 25, 2005) and Hurricane Wilma (October 24, 2005) wind and flood damage to equipment. Field visits and sensor calibration were irregular after 2006, due to curtailed funding. CH3 instantaneous water data are available at South Florida Hydrologic Database, http://sofia.usgs.gov/exchange/sfl_hydro_data/location.html\#brdlandmargin. 


\section{Lostmans Transect}

\section{Lostmans 1 (LO1) Description}

Latitude: $\quad 25^{\circ} 36^{\prime} 44.10^{\prime \prime}$

Longitude: $\quad-81^{\circ} 01^{\prime} 30.94^{\prime \prime}$

UTM Easting Zone 17N: 497489.90

UTM Northing Zone 17N: 2832744.36

Gaging station Operational: March 1, 1996

Gaging station Status: Transferred to USGS Coastal Gradients Study as of October 1, 2012

(Renamed MO-214).

\section{Gaging Station Location}

Gaging station located in a freshwater sawgrass prairie within Everglades National Park and $1 \mathrm{~km}$ south of Coconuts Camp, Big Cypress National Preserve. Accessed by airboat or helicopter.

History

The gaging station consists of two monitoring wells: surface water stilling well is a 12-in. diameter PVC pipe set in marl sediment $(1 \mathrm{ft})$ to bedrock and groundwater well in a drilled bore hole $(7.8 \mathrm{ft})$ through sediment and into the limestone aquifer, cased with a 3 -in. PVC riser and 5-ft screened interval on the bottom (0.02-in. well screen). Groundwater well was drilled on July 20, 1994, and gaging station was operational by March 1, 1996. Gaging station was rebuilt on August 25, 2006, with a wooden frame $1.85 \mathrm{ft}$ higher than previous monitoring platform with new monitoring equipment installed. Gaging station was transferred to USGS-WRD October 1, 2012, and renamed MO-214.

\section{Gaging Station Design}

Data logger, battery, and monitoring instruments are housed within an aluminum housing box on top of a wooden platform supported by four steel pipes. Surface-water and groundwater levels, surface-water and groundwater specific conductance; surface-water and groundwater temperature; and rainfall were monitored. Gaging station was operated by a photovoltaic power system. Radio telemetry was initially used and later GOES satellite transmission was used for daily data transfer.

$\underline{\text { References and Benchmarks }}$

Measurement point (MP) is the aluminum base of the instrument housing on the gaging station platform. A local benchmark is a 3 -in. aluminum cap set on a $5 / 8$-in. rebar driven to refusal within a 3 -in. PVC pipe filled with concrete approximately $10 \mathrm{ft}$ west of gaging station. Vertical (NAVD 88) and horizontal (NAD 83) references were determined by precise differential GPS survey by USGS in 2000, 2001 and 2007 (OPUS solution, GEOID 99).

\begin{tabular}{lccccc}
\hline L01 & Aluminum platform base & 3-in. aluminum cap & \multicolumn{3}{c}{ Ground surface (Marsh) } \\
\hline Reference elevations & Measurement Point & Local Benchmark & Average & Maximum & Minimum \\
(ft, NAVD 88) & 3.85 & 1.52 & -0.03 & 0.07 & -0.21 \\
\hline
\end{tabular}




\section{Lostmans 1 (LO1) Data}

LO1 gaging station was operated for 16.6 years (January 1996-September 2012). Overall, data quality was good. Hourly surface-water level measurements began in 1996 and in 1997 for groundwater levels and salinities. Water temperature and rainfall monitoring began in 2001. Water level time-series measurement interval, except rainfall, was changed to $15 \mathrm{~min}$ in 2006.

\begin{tabular}{|c|c|c|c|c|c|c|c|}
\hline \multirow{2}{*}{$\begin{array}{l}\text { Lostmans } 1 \\
\text { Period of Record (hourly) }\end{array}$} & \multicolumn{3}{|c|}{ Surface water } & \multicolumn{3}{|c|}{ Groundwater } & \multirow[t]{2}{*}{ Rainfall } \\
\hline & Level & Salinity & Temperature & Level & Salinity & Temperature & \\
\hline Begin & 3/1/1996 & 9/12/1997 & $1 / 5 / 2001$ & 10/9/1997 & 10/9/1997 & $1 / 5 / 2001$ & $5 / 7 / 2001$ \\
\hline End & $11 / 15 / 2006$ & $11 / 15 / 2006$ & $11 / 15 / 2006$ & $11 / 15 / 2006$ & $11 / 15 / 2006$ & $11 / 15 / 2006$ & $9 / 30 / 2012$ \\
\hline \multicolumn{8}{|l|}{ Period of Record (15 min) } \\
\hline Begin & $11 / 16 / 2006$ & $11 / 16 / 2006$ & $11 / 16 / 2006$ & $11 / 16 / 2006$ & $11 / 16 / 2006$ & $11 / 16 / 2006$ & \\
\hline End & 9/30/2012 & 9/30/2012 & 9/30/2012 & 9/30/2012 & 9/30/2012 & 9/30/2012 & \\
\hline $\begin{array}{l}\text { Successful collection of } \\
\text { data ( } \% \text { of days during } \\
\text { POR). }\end{array}$ & 84 & 74 & 65 & 84 & 81 & 91 & 91 \\
\hline
\end{tabular}

LO1 data quality was good. Surface-water temperature data collection was limited due to equipment failure. Water pump sampling was not used for salinity measurements. Notably data loss occurred from high water caused by Tropical Storm Harvey (September 21, 1999). Gaging station platform was rebuilt in August 2006 and new monitoring equipment was installed. LO1 instantaneous water data are available at South Florida Hydrologic Database, http://sofia.usgs.gov/exchange/sfl_hydro_data/location.html\#brdlandmargin. 
Lostmans 2 (LO2) Description

Latitude: $\quad 25^{\circ} 35^{\prime} 35.39^{\prime \prime}$

Longitude: $\quad-81^{\circ} 02^{\prime} 29.53$ '

UTM Easting Zone 17N: 495828.96

UTM Northing Zone 17N: 2830630.80

Gaging station Operational: March 1, 1996

Gaging station Status: Transferred to NPS-Everglades October 1, 2012

Gaging Station Location

Gaging station located in a coastal rush marsh, $0.7 \mathrm{~km}$ northeast of NPS gaging station 'Willy Willy', Everglades National Park. Accessed by helicopter.

History

The gaging station consists of two monitoring wells: surface water stilling well is a 12-in. diameter PVC pipe set in marl sediment $(1 \mathrm{ft})$ to bedrock and groundwater well in a drilled bore hole $(4.8 \mathrm{ft})$ through sediment and into the limestone aquifer, cased with a 3-in. PVC riser and $2.5 \mathrm{ft}$ screened interval on the bottom (0.02-in. well screen). Groundwater well was drilled on June 14, 1994, and gaging station was operational by March 1, 1996. Gaging station platform was reconstructed February 25, 2010, with a stainless steel frame $0.26 \mathrm{ft}$ higher than previous monitoring platform with new monitoring equipment installed. Gaging station was transferred to NPS-Everglades October 1, 2012.

\section{Gaging Station Design}

Data logger, battery, and monitoring instruments are housed within an aluminum housing box on top of a wooden platform (rebuilt with stainless steel) supported by four steel pipes. Surface-water and groundwater levels, surface-water and groundwater specific conductance; surface-water and groundwater temperature; and rainfall were monitored. Gaging station was operated by a photovoltaic power system. Radio telemetry was initially used and later GOES satellite transmission was used for daily data transfer.

$\underline{\text { References and Benchmarks }}$

Measurement point (MP) is the aluminum base of the instrument housing on the gaging station platform. A local benchmark is a 3-in. aluminum cap set on a 5/8-in. rebar driven to refusal within a 3 -in. PVC pipe filled with concrete approximately $8 \mathrm{ft}$ north of gaging station. Vertical (NAVD 88) and horizontal (NAD 83) references were determined by precise differential GPS survey by USGS in 2000, 2001, and 2007 (OPUS solution, GEOID 99).

\begin{tabular}{lccccc}
\hline LO2 & Aluminum platform base & 3-in. aluminum cap & \multicolumn{3}{c}{ Ground surface (Marsh) } \\
\hline Reference elevations & Measurement point & Local benchmark & Average & Maximum & Minimum \\
(ft, NAVD 88) & 2.88 & 0.34 & -0.66 & -0.52 & -0.74 \\
\hline
\end{tabular}




\section{Lostmans 2 (LO2) Data}

LO2 gaging station was operated for 16.6 years (January 1996-September 2012). Overall, data quality was good. Hourly surface-water and groundwater monitoring record began in 1996 for water levels and salinities. Groundwater temperature monitoring began in 2000 and in 2002 for surface water. Water temperature began in 2000 and rainfall in 2001. Water level time-series measurement interval, except rainfall, was changed to $15 \mathrm{~min}$ in 2007.

\begin{tabular}{|c|c|c|c|c|c|c|c|}
\hline \multirow{2}{*}{$\begin{array}{l}\text { Lostmans } 2 \\
\text { Period of record (hourly) }\end{array}$} & \multicolumn{3}{|c|}{ Surface water } & \multicolumn{3}{|c|}{ Groundwater } & \multirow[t]{2}{*}{ Rainfall } \\
\hline & Level & Salinity & Temperature & Level & Salinity & Temperature & \\
\hline Begin & 3/1/1996 & $5 / 6 / 1996$ & $10 / 25 / 2000$ & 3/1/1996 & $5 / 6 / 1996$ & $10 / 25 / 2000$ & 7/18/2001 \\
\hline End & $5 / 7 / 2007$ & $5 / 7 / 2007$ & $5 / 7 / 2007$ & $5 / 7 / 2007$ & $2 / 28 / 2007$ & $2 / 28 / 2007$ & 9/30/2012 \\
\hline \multicolumn{8}{|l|}{ Period of record (15 min) } \\
\hline Begin & $5 / 8 / 2007$ & $5 / 8 / 2007$ & $5 / 8 / 2007$ & $5 / 8 / 2007$ & 3/1/2007 & $3 / 1 / 2007$ & \\
\hline End & 9/30/2012 & $9 / 30 / 2012$ & 9/30/2012 & $9 / 30 / 2012$ & 9/30/2012 & 9/30/2012 & \\
\hline $\begin{array}{l}\text { Successful collection of } \\
\text { data (\% of days during } \\
\text { POR). }\end{array}$ & 87 & 64 & 81 & 82 & 82 & 92 & 98 \\
\hline
\end{tabular}

LO2 data quality was good. However, surface water salinity data were limited due to equipment failure. Water pumping to sample surface water salinity was used for 2 years with modest success, but was discontinued because of excessive maintenance and equipment failure. New monitoring equipment was added in 2006 and the platform was rebuilt with stainless steel frame in August 2009. LO2 instantaneous water data are available at South Florida Hydrologic Database, http://sofia.usgs.gov/exchange/sfl_hydro_data/location.html\#brdlandmargin. 
Lostmans 3 (LO3) Description

Latitude: $\quad 25^{\circ} 32^{\prime} 21.21^{\prime \prime}$

Longitude: $\quad-81^{\circ} 11^{\prime} 03.44^{\prime \prime}$

UTM Easting Zone 17N: 481485.43

UTM Northing Zone 17N: 2824670.38

Gaging station Operational: January 1, 1996

Gaging station Status: Discontinued August 30, 2012

Gaging Station Location

Gaging station located in a riverine mangrove forest near Johnson Creek, $0.8 \mathrm{~km}$ southeast of First Bay of the Lostmans River, Everglades National Park. Accessed only at high tide by boat. Local knowledge is recommended to avoid grounding.

\section{History}

The gaging station consists of two monitoring wells: surface water stilling well is a 12 -in. diameter PVC pipe set in peat sediment (11 ft) to bedrock and groundwater well in a drilled bore hole ( $24 \mathrm{ft})$ through peat and into the limestone aquifer, cased with a 3 -in. PVC riser and 5-ft screened interval on the bottom (0.02-in. well screen). Groundwater well was drilled on May 16, 1994, and gaging station was operational by January 1, 1996. Gaging station was rebuilt on July 25, 2003, with a wooden frame platform $2.25 \mathrm{ft}$ higher than previous monitoring platform with new monitoring equipment installed. Hurricane Wilma (October 24, 2005) flood damage ruined monitoring equipment. Replacement equipment was installed on October 20, 2006. Gaging station was discontinued on August 30, 2012.

\section{Gaging Station Design}

Data logger, battery, and monitoring instruments are housed within an aluminum housing box on top of a wooden platform supported by four steel pipes. Surface-water and groundwater levels, surface-water and groundwater specific conductance, and surface-water and groundwater temperature were monitored. Gaging station was operated by a photovoltaic power system. Radio telemetry was initially used and later GOES satellite transmission was used for daily data transfer.

References and Benchmarks

Measurement point (MP) is the aluminum base of the instrument housing on the gaging station platform. A local benchmark is a 3 -in. aluminum cap set on a $5 / 8$-in. rebar driven to refusal within a 3 -in. PVC pipe filled with concrete approximately $4 \mathrm{ft}$ north of gaging station. Vertical (NAVD 88) and horizontal (NAD 83) references were determined by precise differential GPS survey by USGS in 2001, 2002, 2003, and 2007 (OPUS solution, GEOID 99).

\begin{tabular}{lccccc}
\hline LO3 & Aluminum platform base & 3-in. aluminum cap & \multicolumn{2}{c}{ Ground surface (Mangrove) } \\
\hline Reference elevations & Measurement point & Local benchmark & Average & Maximum & Minimum \\
(ft, NAVD 88) & 6.10 & 2.28 & 1.14 & 1.17 & 1.08 \\
\hline
\end{tabular}




\section{Lostmans 3 (LO3) Data}

LO3 gaging station was operated for 16.7 years (January 1996-September 2012). Overall, data quality was fair, because of the impact the harsh coastal saline environment and dense tree canopy had on sensor reliability, PV power and data transmission. Hourly surface-water and groundwater monitoring record began in 1996 for water levels and in 1997 for salinities. Groundwater temperature monitoring began in 2002 and in 2003 for surface water. Water level time-series measurement interval was changed to $15 \mathrm{~min}$ in 2003 for water levels and in 2007 for salinity and temperature.

\begin{tabular}{|c|c|c|c|c|c|c|}
\hline \multirow{2}{*}{$\begin{array}{l}\text { Lostmans } 3 \\
\text { Period of record (hourly) }\end{array}$} & \multicolumn{3}{|c|}{ Surface water } & \multicolumn{3}{|c|}{ Groundwater } \\
\hline & Level & Salinity & Temperature & Level & Salinity & Temperature \\
\hline Begin & 1/1/1996 & $4 / 24 / 1997$ & $8 / 11 / 2003$ & $1 / 1 / 1996$ & 10/13/1997 & $7 / 11 / 2002$ \\
\hline End & $8 / 10 / 2003$ & $5 / 13 / 2007$ & $5 / 13 / 2007$ & $8 / 10 / 2003$ & $5 / 13 / 2007$ & $5 / 13 / 2007$ \\
\hline \multicolumn{7}{|l|}{ Period of record (15 $\mathrm{min}$ ) } \\
\hline Begin & $8 / 11 / 2003$ & $5 / 14 / 2007$ & $5 / 14 / 2007$ & $8 / 11 / 2003$ & $5 / 14 / 2007$ & $5 / 14 / 2007$ \\
\hline End & $3 / 24 / 2012$ & $3 / 16 / 2012$ & $3 / 16 / 2012$ & $8 / 20 / 2012$ & $12 / 19 / 2011$ & 2/4/2012 \\
\hline $\begin{array}{l}\text { Successful collection of } \\
\text { data (\% of days during } \\
\text { POR). }\end{array}$ & 66 & 53 & 69 & 64 & 56 & 73 \\
\hline
\end{tabular}

Overall, LO3 data quality was fair due to harsh site conditions and there was substantial data loss due to chronic equipment failure. Water pumping to sample surface water salinity was used for less than 1 year with poor results and was discontinued because of excessive maintenance and equipment failure. New platform was rebuilt and new monitoring equipment was added in June 2003. Hurricane Katrina (August 25, 2005) and Hurricane Wilma (October 24, 2005) flooding and high winds caused catastrophic equipment failure and a 10-month loss of gaging station monitoring. LO3 instantaneous water data are available at South Florida Hydrologic Database, http://sofia.usgs.gov/exchange/sfl_hydro_data/location.html\#brdlandmargin. 
Lostmans 4 (LO4) Description

Latitude: $\quad 25^{\circ} 30^{\prime} 23.19^{\prime \prime}$

Longitude: $\quad-81^{\circ} 09^{\prime} 59.51^{\prime \prime}$

UTM Easting Zone 17N: 483252.67

UTM Northing Zone 17N: 2821037.53

Gaging station Operational: January 1, 1996

Gaging station Status: Discontinued March 15, 2004

Gaging Station Location

Gaging station is located in a coastal cordgrass (Spartina) marsh surrounded by mangrove forest, $4 \mathrm{~km}$ south of LO3 gaging station and $4 \mathrm{~km}$ east of Highland Beach, Gulf of Mexico, and Everglades National Park. Accessed only by helicopter.

\section{History}

The gaging station consists of two monitoring wells: surface water stilling well is a 12-in. diameter PVC pipe set in peat sediment $(10 \mathrm{ft})$ to bedrock and groundwater well in a drilled bore hole $(14 \mathrm{ft})$ through sediment and into the limestone aquifer, cased with a 3 -in. PVC riser and 5-ft screened interval on the bottom (0.02-in. well screen). Groundwater well was drilled on May 18, 1994, and gaging station was operational by January 1, 1996. Gaging station was rebuilt on May 7, 2003, with a wooden frame $2.76 \mathrm{ft}$ higher and new monitoring equipment was installed. Gaging station was discontinued on March 15, 2004 .

\section{Gaging Station Design}

Data logger, battery, and monitoring instruments are housed within an aluminum housing box on top of a wooden platform supported by four steel pipes. Surface-water and groundwater levels, surface-water and groundwater specific conductance; surface-water and groundwater temperature; and rainfall were monitored. Gaging station was operated by a photovoltaic power system. Radio telemetry was initially used and later GOES satellite transmission was used for daily data transfer.

$\underline{\text { References and Benchmarks }}$

Measurement point (MP) is the aluminum base of the instrument housing on the gaging station platform. A local benchmark is a 3 -in. aluminum cap set on a $5 / 8$-in. rebar driven to refusal within a 3 -in. PVC pipe filled with concrete approximately $6 \mathrm{ft}$ north of gaging station. Vertical (NAVD 88) and horizontal (NAD 83) references were determined by precise differential GPS survey by USGS in 2001 and 2003 (OPUS solution, GEOID 99).

\begin{tabular}{lccccc}
\hline Lostmans 4 & Aluminum platform base & 3-in. aluminum cap & \multicolumn{2}{c}{ Ground surface (Marsh) } \\
\hline Reference elevations & Measurement point & Local benchmark & Average & Maximum & Minimum \\
(ft, NAVD 88) & 4.77 & 0.94 & 0.51 & 0.63 & 0.39 \\
\hline
\end{tabular}




\section{Lostmans 4 (LO4) Data}

LO4 gaging station was operated for 8.25 years (January 1996-March 2004). Overall, data quality was good. Hourly surface-water and groundwater monitoring record began in 1996 for water levels and in 1997 for salinities and rainfall. Groundwater temperature monitoring began in 2000 and in 2003 for surface water.

\begin{tabular}{|c|c|c|c|c|c|c|c|}
\hline \multirow{2}{*}{$\begin{array}{l}\text { Lostmans } 4 \\
\text { Period of record (hourly) }\end{array}$} & \multicolumn{3}{|c|}{ Surface water } & \multicolumn{3}{|c|}{ Groundwater } & \multirow[t]{2}{*}{ Rainfall } \\
\hline & Level & Salinity & Temperature & Level & Salinity & Temperature & \\
\hline Begin & 1/1/1996 & 6/18/1997 & $5 / 7 / 2003$ & 1/1/1996 & 6/18/1997 & $4 / 16 / 2000$ & 10/1/1997 \\
\hline End & $3 / 15 / 2004$ & $3 / 15 / 2004$ & $3 / 15 / 2004$ & $3 / 15 / 2004$ & $3 / 15 / 2004$ & $3 / 15 / 2004$ & 3/15/2004 \\
\hline $\begin{array}{l}\text { Successful collection of } \\
\text { data (\% of days during } \\
\text { POR). }\end{array}$ & 67 & 64 & 100 & 71 & 45 & 77 & 78 \\
\hline
\end{tabular}

Overall, LO4 data quality was good, although data were diminished due to infrequent site visits because of limited access to this remote site. Groundwater salinity data collection was diminished due to equipment failure. Salinity data quality especially suffered because of limited access to this remote gaging station for field calibration. Water pumping to sample salinity was not used successfully. New platform was rebuilt and new monitoring equipment was added in March 2003. Gaging station was discontinued in March 2004, due to curtailed funding. LO4 instantaneous water data are available at South Florida Hydrologic Database, http://sofia.usgs.gov/exchange/sfl_hydro_data/location.html\#brdlandmargin. 


\section{Shark Transect}

Shark 1 (SH1) Description

Latitude: $\quad 25^{\circ} 28^{\prime} 20.65^{\prime \prime}$

Longitude: $\quad-80^{\circ} 50^{\prime} 53.59^{\prime \prime}$

UTM Easting Zone 17N: 515257.11

UTM Northing Zone 17N: 2817266.59

Gaging station Operational: January 11, 1996

Gaging station Status: Transferred to USGS Coastal Gradients Study as of October 1, 2012

(Renamed MO-215)

Gaging Station Location

Gaging station is located in a freshwater sawgrass marsh along the Shark River Slough, $0.7 \mathrm{~km}$ northeast of Rookery Branch, Everglades National Park. Accessed by airboat or helicopter.

History

The gaging station consists of two monitoring wells: surface water stilling well is a 12-in. diameter PVC pipe set in muck sediment $(3 \mathrm{ft})$ to bedrock and groundwater well in a drilled bore hole $(11 \mathrm{ft})$ through sediment and into the limestone aquifer, cased with a 3-in. PVC riser and 5-ft screened interval on the bottom (0.02-in. well screen). Groundwater well was drilled on December 28, 1993, and gaging station was operational by January 11, 1996.Gaging station was rebuilt on July 21, 2003, with a wooden frame $1.04 \mathrm{ft}$ higher than previous monitoring platform with new monitoring equipment installed. Gaging station was transferred to USGS-WRD on October 1, 2012, and renamed MO-215.

\section{Gaging Station Design}

Data logger, battery, and monitoring instruments are housed within an aluminum housing box on top of a wooden platform supported by four steel pipes. Surface-water and groundwater levels, surface-water and groundwater specific conductance; surface-water and groundwater temperature; and rainfall were monitored. Gaging station was operated by a photovoltaic power system. Radio telemetry was initially used and later GOES satellite transmission was used for daily data transfer.

$\underline{\text { References and Benchmarks }}$

Measurement point (MP) is the aluminum base of the instrument housing on the gaging station platform. A local benchmark is a 3-in. aluminum cap set on a 5/8-in. rebar driven to refusal within a 3 -in. PVC pipe filled with concrete approximately $4 \mathrm{ft}$ west of gaging station. Vertical (NAVD 88) and horizontal (NAD 83) references were determined by precise differential GPS survey by USGS in 2002, 2003, and 2007 (OPUS solution, GEOID 99).

\begin{tabular}{lccccc}
\hline Shark 1 & Aluminum platform base & 3-in. aluminum cap & \multicolumn{3}{c}{ Ground surface (Marsh) } \\
\hline Reference elevations & Measurement point & Local benchmark & Average & Maximum & Minimum \\
(ft, NAVD 88) & 5.38 & 1.79 & -0.32 & -0.24 & -0.49 \\
\hline
\end{tabular}




\section{Shark 1 (SH1) Data}

SH1 gaging station was operated for 16.75 years (January 1996-September 2012). Overall, data quality was good-excellent. Hourly surface-water and groundwater monitoring record began in 1996 for water levels and surface water salinity and in 1997 for groundwater salinity. Groundwater temperature monitoring started in 1999 and in 2000 for surface water and rainfall. Water level time-series measurement interval was changed to 15 min for water levels and surface water salinity and temperature in 2006 and for groundwater salinity and temperature in 2007.

\begin{tabular}{|c|c|c|c|c|c|c|c|}
\hline \multirow{2}{*}{$\begin{array}{l}\text { Shark } 1 \\
\text { Period of record (hourly) }\end{array}$} & \multicolumn{3}{|c|}{ Surface water } & \multicolumn{3}{|c|}{ Groundwater } & \multirow[t]{2}{*}{ Rainfall } \\
\hline & Level & Salinity & Temperature & Level & Salinity & Temperature & \\
\hline Begin & $1 / 11 / 1996$ & $5 / 7 / 1996$ & $8 / 16 / 2000$ & $1 / 11 / 1996$ & $6 / 12 / 1997$ & 12/8/1999 & 9/5/2000 \\
\hline End & $10 / 17 / 2006$ & $12 / 13 / 2006$ & $12 / 13 / 2006$ & $10 / 17 / 2006$ & $1 / 17 / 2007$ & $1 / 17 / 2007$ & 9/30/2012 \\
\hline \multicolumn{8}{|l|}{ Period of record (15 $\mathrm{min}$ ) } \\
\hline Begin & $1 / 18 / 2006$ & $12 / 14 / 2006$ & $12 / 14 / 2006$ & $1 / 18 / 2006$ & $1 / 18 / 2007$ & $1 / 18 / 2007$ & \\
\hline End & 9/30/2012 & 9/30/2012 & 9/30/2012 & 9/30/2012 & 9/30/2012 & 9/30/2012 & \\
\hline $\begin{array}{l}\text { Daily data successfully } \\
\text { collected ( } \% \text { of days } \\
\text { during POR).( } \% \text { of days }\end{array}$ & 94 & 92 & 92 & 87 & 87 & 92 & 94 \\
\hline
\end{tabular}

SH1 data quality was good. Water pumping to sample salinity was used for 2 years with modest success, but was discontinued because of excessive maintenance and equipment failure. Notably data loss occurred from high water caused by Tropical Storm Harvey (September 21, 1999) and storm damage from Hurricane Katrina (August 25, 2005). Gaging station platform was rebuilt in August 2003 and new monitoring equipment was installed. SH1 instantaneous water data are available at South Florida Hydrologic Database, http://sofia.usgs.gov/exchange/sfl_hydro_data/location.html\#brdlandmargin. 
Shark 2 (SH2) Description

Latitude: $\quad 25^{\circ} 24^{\prime} 36.22^{\prime \prime}$

Longitude: $\quad-80^{\circ} 57^{\prime} 47.88^{\prime \prime}$

UTM Easting Zone 17N: 503691.00

UTM Northing Zone 17N: 2810354.99

Gaging station Operational: June 6, 1995

Gaging station Status: Transferred to FCE-LTER October 1, 2012

Gaging Station Location

Gaging station is located in an estuarine sawgrass /rush marsh surrounded by mangrove and buttonwood forest, $0.1 \mathrm{~km}$ east of NPS gaging station 'Tarpon East', Tarpon Bay, Everglades National Park. Accessed by boat.

History

The gaging station consists of two monitoring wells: surface water stilling well is a 12-in. diameter PVC pipe set in peat sediment $(6 \mathrm{ft})$ to bedrock and groundwater well in a drilled bore hole $(12 \mathrm{ft})$ through sediment and into the limestone aquifer, cased with a 3-in. PVC riser and 7-ft screened interval on the bottom (0.02-in. well screen). Groundwater well drilled on April 11, 1994, and gaging station was operational by June 6, 1995. Gaging station was rebuilt on February 12, 2003 with a wooden frame 2.10 $\mathrm{ft}$ higher than previous monitoring platform with new monitoring equipment installed. Gaging station was transferred to FCE-LTER on October 1, 2012.

Gaging Station Design

Data logger, battery, and monitoring instruments are housed within an aluminum housing box on top of a wooden platform supported by four steel pipes. Surface-water and groundwater levels, surface-water and groundwater specific conductance, surface-water and groundwater temperature, and rainfall were monitored. A second groundwater conductivity/temperature was installed on January 8, 2008, $1 \mathrm{~m}$ deeper in well to evaluate salinity density. Gaging station was operated by a photovoltaic power system. Radio telemetry was initially used and later GOES satellite was used transmission for daily data transfer.

$\underline{\text { References and Benchmarks }}$

Measurement point (MP) is the aluminum base of the instrument housing on the gaging station platform. A local benchmark is a 3-in. aluminum cap set on a 5/8-in. rebar driven to refusal within a 3 -in. PVC pipe filled with concrete approximately $4 \mathrm{ft}$ east of gaging station. Vertical (NAVD 88) and horizontal (NAD 83) references were determined by precise differential GPS survey by USGS-NMD and USGS-GD in 2001 and 2002 (OPUS solution, GEOID 99).

\begin{tabular}{lccccc}
\hline Shark 2 & Aluminum platform base & 3-in. aluminum cap & \multicolumn{3}{c}{ Ground surface (Marsh) } \\
\hline Reference elevations & Measurement point & Local benchmark & Average & Maximum & Minimum \\
(ft, NAVD 88) & 4.17 & 0.88 & -0.52 & -0.32 & -0.69 \\
\hline
\end{tabular}




\section{Shark 2 (SH2) Data}

SH2 gaging station was operated for 17.3 years (June 1995-September 2012). Overall, data quality was good-excellent. Hourly surface and groundwater level monitoring in began in 1995 (water year 1996). Both surface water and groundwater salinity measurements begin in 1996 and water temperature monitoring was started in 1999. Rainfall monitoring began in 2001. Surface water level time-series measurement interval was changed to $15 \mathrm{~min}$ in 2003 and groundwater level, salinity, and temperature parameters in 2008. A second groundwater salinity/temperature sensor was installed in January 2008 to better characterize salinity variability in well.

\begin{tabular}{|c|c|c|c|c|c|c|c|c|c|}
\hline \multirow{2}{*}{$\begin{array}{l}\text { Shark } 2 \\
\text { Period of record (hourly) }\end{array}$} & \multicolumn{3}{|c|}{ Surface water } & \multicolumn{3}{|c|}{ Groundwater } & \multicolumn{2}{|c|}{ Groundwater 2} & \multirow[t]{2}{*}{ Rainfall } \\
\hline & Level & Salinity & Temperature & Level & Salinity & Temperature & Salinity & Temperature & \\
\hline Begin & 6/6/1995 & 4/18/1996 & 4/20/1999 & 12/7/1995 & 4/18/1996 & 4/20/1999 & $1 / 8 / 2008$ & $1 / 8 / 2008$ & 10/5/2001 \\
\hline End & $2 / 11 / 2003$ & $3 / 25 / 2008$ & $3 / 25 / 2008$ & $2 / 11 / 2003$ & $8 / 3 / 2010$ & $8 / 3 / 2010$ & $3 / 25 / 2008$ & $3 / 25 / 2008$ & $9 / 30 / 2012$ \\
\hline \multicolumn{10}{|l|}{ Period of record (15 min) } \\
\hline Begin & $2 / 12 / 2003$ & $3 / 26 / 2008$ & $3 / 26 / 2008$ & $2 / 12 / 2003$ & $8 / 4 / 2010$ & $8 / 4 / 2010$ & $3 / 26 / 2008$ & $3 / 26 / 2008$ & \\
\hline End & $9 / 30 / 2012$ & 9/30/2012 & 9/30/2012 & $9 / 30 / 2012$ & 9/30/2012 & $9 / 30 / 2012$ & $9 / 30 / 2012$ & $9 / 30 / 2012$ & \\
\hline $\begin{array}{l}\text { Daily data successfully } \\
\text { collected (\% of days during } \\
\text { POR). }\end{array}$ & 97 & 84 & 91 & 91 & 71 & 65 & 99 & 99 & 99 \\
\hline
\end{tabular}

SH2 data quality was good. Water pumping to sample salinity was used for 5 years with modest success, but was discontinued because of excessive maintenance and equipment failure. Gaging station platform was rebuilt in January 2003 and new monitoring equipment was installed. SH2 instantaneous water data are available at South Florida Hydrologic Database, http://sofia.usgs.gov/exchange/sfl_hydro_data/location.html\#brdlandmargin. 
Shark 3 (SH3) Description

Latitude: $\quad 25^{\circ} 21^{\prime} 50.74^{\prime \prime}$

Longitude: $\quad-81^{\circ} 04^{\prime} 42.53^{\prime \prime}$

UTM Easting Zone 17N: 492115.47

UTM Northing Zone 17N: 2824659.87

Gaging station Operational: October 1, 1995

Gaging station Status: Transferred to FCE-LTER October 1, 2012

Gaging Station Location

Gaging station is located in a riverine mangrove forest adjacent to the Shark River, $4 \mathrm{~km}$ northeast of Ponce de Leon Bay, Everglades National Park. Accessed by boat.

History

The gaging station consists of two monitoring wells: surface water stilling well is a 12-in. diameter PVC pipe set in peat sediment (18 ft) to bedrock and groundwater well in a drilled bore hole ( $24 \mathrm{ft})$ through sediment and into the limestone aquifer, cased with a 3 -in. PVC riser and 5-ft screened interval on the bottom (0.02-in. well screen). Groundwater well drilled on April 18, 1994, and gaging station was operational by October 1, 1995. Gaging station was rebuilt on January 20, 2003, with a wooden frame $2.48 \mathrm{ft}$ higher than previous monitoring platform with new monitoring equipment installed. Hurricane Wilma (October 24, 2005) flood damage ruined monitoring equipment. Replacement equipment was installed on August 17, 2006. Gaging station was transferred to FCE-LTER on October 1, 2012.

\section{Gaging Station Design}

Data logger, battery, and monitoring instruments are housed within an aluminum housing box on top of a wooden platform supported by four steel pipes. Surface and groundwater levels, surface and groundwater specific conductance; surface and groundwater temperature were monitored. Gaging station was operated by a photovoltaic power system. Radio telemetry was initially used and later GOES satellite transmission was used for daily data transfer.

References and Benchmarks

Measurement point (MP) is the aluminum base of the instrument housing on the gaging station platform. A local benchmark is a 3 -in. aluminum cap set on a 5/8-in. rebar driven to refusal within a 3 -in. PVC pipe filled with concrete approximately $3 \mathrm{ft}$ east of gaging station. Vertical (NAVD 88) and horizontal (NAD 83) references were determined by precise differential GPS survey by USGS in 2002, 2003, and 2007 (OPUS solution, GEOID 99).

\begin{tabular}{lccccc}
\hline Shark 3 & Aluminum platform base & 3-in. aluminum cap & \multicolumn{2}{c}{ Ground surface (Mangrove) } \\
\hline Reference elevations & Measurement point & Local benchmark & Average & Maximum & Minimum \\
(ft, NAVD 88) & 5.08 & 1.85 & 0.27 & 0.36 & 0.13 \\
\hline
\end{tabular}




\section{Shark 3 (SH3) Data}

SH3 gaging station was operated for 16.9 years (October 1995-September 2012). Overall, data quality was fair, because of the impact the harsh coastal saline environment and dense tree canopy had on sensor reliability, PV power and data transmission. Overall, data quality was good-excellent. Hourly surface-water and groundwater level monitoring in began in 1995 (water year 1996). Both surface water and groundwater salinity measurements begin in 1996 and water temperature monitoring was started in 1999. Water level time-series measurement interval was changed to $15 \mathrm{~min}$ in 2003 and for salinity and temperature in 2007.

\begin{tabular}{|c|c|c|c|c|c|c|}
\hline \multirow{2}{*}{$\begin{array}{l}\text { Shark } 3 \\
\text { Period of record (hourly) }\end{array}$} & \multicolumn{3}{|c|}{ Surface water } & \multicolumn{3}{|c|}{ Groundwater } \\
\hline & Level & Salinity & Temperature & Level & Salinity & Temperature \\
\hline Begin & 10/1/1995 & $5 / 13 / 1996$ & $4 / 20 / 1999$ & 10/1/1995 & $5 / 13 / 1996$ & 4/20/1999 \\
\hline End & $1 / 16 / 2003$ & $4 / 9 / 2007$ & $4 / 9 / 2007$ & $1 / 16 / 2003$ & $4 / 9 / 2007$ & $4 / 9 / 2007$ \\
\hline \multicolumn{7}{|l|}{ Period of record (15 min) } \\
\hline Begin & 1/17/2003 & 4/10/2007 & 4/10/2007 & 1/17/2003 & 4/10/2007 & 4/10/2007 \\
\hline End & $9 / 30 / 2012$ & 9/30/2012 & $9 / 30 / 2012$ & 9/30/2012 & $9 / 30 / 2012$ & 9/30/2012 \\
\hline $\begin{array}{l}\text { Successful collection of } \\
\text { data (\% of days during } \\
\text { POR). }\end{array}$ & 76 & 70 & 81 & 77 & 68 & 72 \\
\hline
\end{tabular}

Overall, SH3 data quality was good, but due to harsh site conditions, there was data loss, due to equipment failure. Water pumping to sample salinity was used for 5 years with fair success and was discontinued because of excessive maintenance and equipment failure. Gaging station platform was rebuilt in January 2003 and new monitoring equipment was installed. Notable data loss occurred from Tropical Storm Harvey (September 21, 1999); Hurricane Katrina (August 25, 2005) and Hurricane Wilma (October 24, 2005) flooding and high winds caused catastrophic equipment failure and a 10-month loss of gaging station monitoring. SH3 instantaneous water data are available at South Florida Hydrologic Database, http://sofia.usgs.gov/exchange/sfl_hydro_data/location.html\#brdlandmargin. 
Shark 4 (SH4) Description

Latitude: $\quad 25^{\circ} 25^{\prime} 24.55^{\prime \prime}$

Longitude: $\quad-81^{\circ} 03^{\prime} 37.61^{\prime \prime}$

UTM Easting Zone 17N: 493921.38

UTM Northing Zone 17N: 2811842.48

Gaging station Operational: January 27, 1995

Gaging station Status: Discontinued September 26, 2012

Gaging Station Location

Gaging station is located in a riverine mangrove forest adjacent to Harney River, $5 \mathrm{~km}$ northwest of Tarpon Bay, Everglades National Park. Accessed by boat or helicopter via walkway linked to USGS gaging station 'SH5'.

\section{History}

The gaging station consists of two monitoring wells: surface water stilling well is a 12-in. diameter PVC pipe set in peat sediment $(10 \mathrm{ft})$ to bedrock and groundwater well in a drilled bore hole $(17 \mathrm{ft})$ through sediment and into the limestone aquifer, cased with a 3 -in. PVC riser and 5-ft screened interval on the bottom (0.02-in. well screen). Groundwater well drilled on April 13, 1994, and gaging station was operational by January 27, 1995. Gaging station was rebuilt on February 5, 2003, with a wooden frame $2.78 \mathrm{ft}$ higher than previous monitoring platform with new monitoring equipment installed. Gaging station was discontinued on September 26, 2012.

\section{Gaging Station Design}

Data logger, battery, and monitoring instruments are housed within an aluminum housing box on top of a wooden platform supported by four steel pipes. Surface-water and groundwater levels, surface-water and groundwater specific conductance; surface-water and groundwater temperature were monitored. Gaging station was operated by a photovoltaic power system. Radio telemetry was initially used and later GOES satellite transmission was used for daily data transfer.

$\underline{\text { References and Benchmarks }}$

Measurement point (MP) is the aluminum base of the instrument housing on the gaging station platform. A local benchmark is a 3 -in. aluminum cap set on a $5 / 8$-in. rebar driven to refusal within a 3 -in. PVC pipe filled with concrete approximately $4 \mathrm{ft}$ south of gaging station. Vertical (NAVD 88) and horizontal (NAD 83) references were determined by precise differential GPS survey by USGS in 2001 and 2007 (OPUS solution, GEOID 99).

\begin{tabular}{lccccc}
\hline Shark 4 & Aluminum platform base & 3-in. aluminum cap & \multicolumn{3}{c}{ Ground surface (Mangrove) } \\
\hline Reference elevations & Measurement point & Local benchmark & Average & Maximum & Minimum \\
(ft, NAVD 88) & 5.23 & 1.63 & 0.37 & 0.42 & 0.32 \\
\hline
\end{tabular}




\section{Shark 4 (SH4) Data}

SH4 gaging station was operated for 17.75 years (January 1995-September 2012). Overall, data quality was good. Hourly surface-water and groundwater level monitoring in began in 1995 (water year 1996). Both surface-water and groundwater salinity measurements begin in 1996 and water temperature monitoring was started in 1999. Water level time-series measurement interval was changed to 15 min in 2003 and for salinity and temperature in 2008.

\begin{tabular}{lcccccc}
\hline Shark 4 & \multicolumn{3}{c}{ Surface water } & \multicolumn{3}{c}{ Groundwater } \\
\hline Period of record (hourly) & Level & Salinity & Temperature & Level & Salinity & Temperature \\
Begin & $1 / 27 / 1995$ & $4 / 28 / 1996$ & $7 / 1 / 1999$ & $1 / 27 / 1995$ & $4 / 28 / 1996$ & $5 / 4 / 1999$ \\
End & $2 / 4 / 2003$ & $3 / 18 / 2008$ & $3 / 18 / 2008$ & $2 / 4 / 2003$ & $3 / 18 / 2008$ & $3 / 18 / 2008$ \\
Period of record (15 $\mathbf{m i n})$ & & & & & & \\
Begin & $2 / 5 / 2003$ & $3 / 19 / 2008$ & $3 / 19 / 2008$ & $2 / 5 / 2003$ & $3 / 19 / 2008$ & $3 / 19 / 2008$ \\
End & $9 / 26 / 2012$ & $9 / 26 / 2012$ & $9 / 26 / 2012$ & $9 / 26 / 2012$ & $9 / 26 / 2012$ & $9 / 26 / 2012$ \\
$\begin{array}{l}\text { Successful collection of (\% } \\
\text { of days during POR). }\end{array}$ & 88 & 79 & 79 & 81 & 77 & 77 \\
\hline
\end{tabular}

SH4 data quality was good. Water pumping to sample salinity was used for 5 years with modest success, but was discontinued because of excessive maintenance and equipment failure. Gaging station platform was rebuilt in January 2003 and new monitoring equipment was installed. Hurricane Katrina (August 25, 2005) and Hurricane Wilma (October 24, 2005) caused notable wind and water damage to equipment. SH4 instantaneous water data are available at South Florida Hydrologic Database, http://sofia.usgs.gov/exchange/sfl_hydro_data/location.html\#brdlandmargin. 
Shark 5 (SH5) Description

Latitude: $\quad 25^{\circ} 25^{\prime} 16.77^{\prime \prime}$

Longitude: $\quad-81^{\circ} 03^{\prime} 34.89^{\prime \prime}$

UTM Easting Zone 17N: 493997.24

UTM Northing Zone 17N: 2811603.13

Gaging station Operational: October 12, 1995

Gaging station Status: Discontinued September 26, 2012

Gaging Station Location

Gaging station is located in a coastal sawgrass marsh near a fringe mangrove forest that extends $0.3 \mathrm{~km}$ north to south edge of the Harney River, Everglades National Park. Accessed by helicopter or boat via walkway linked to USGS gaging station 'SH4'.

\section{History}

The gaging station consists of two monitoring wells: surface water stilling well is a 12-in. diameter PVC pipe set in peat sediment $(8 \mathrm{ft}$ ) to bedrock and groundwater well in a drilled bore hole (16 ft) through sediment and into the limestone aquifer, cased with a 3 -in. PVC riser and 5-ft screened interval on the bottom (0.02-in. well screen). Groundwater well was drilled on April 28, 1995, and gaging station was operational by October 12, 1995. Gaging station was rebuilt on February 5, 2003, with a wooden frame $2.22 \mathrm{ft}$ higher than previous monitoring platform with new monitoring equipment installed. Gaging station was discontinued on September 26, 2012.

\section{Gaging Station Design}

Data logger, battery, and monitoring instruments are housed within an aluminum housing box on top of a wooden platform supported by four steel pipes. Surface-water and groundwater levels, surface-water and groundwater specific conductance, surface-water and groundwater temperature, and rainfall were monitored. Gaging station was operated by a photovoltaic power system. Radio telemetry was initially used and later GOES satellite was used transmission for daily data transfer.

$\underline{\text { References and Benchmarks }}$

Measurement point (MP) is the aluminum base of the instrument housing on the gaging station platform. A local benchmark is a 3 -in. aluminum cap set on a 5/8-in. rebar driven to refusal within a 3 -in. PVC pipe filled with concrete approximately $4 \mathrm{ft}$ south of gaging station. Vertical (NAVD 88) and horizontal (NAD 83) references were determined by precise differential GPS survey by USGS in 2000, 2001, 2002, 2003 and 2007 (OPUS solution, GEOID 99).

\begin{tabular}{lccccc}
\hline Shark 5 & Aluminum platform base & 3-in. aluminum cap & \multicolumn{3}{c}{ Ground surface (Marsh) } \\
\hline Reference elevations & Measurement point & Local benchmark & Average & Maximum & Minimum \\
(ft, NAVD 88) & 4.71 & 0.57 & 0.16 & 0.31 & 0.10 \\
\hline
\end{tabular}




\section{Shark 5 (SH5) Data}

SH5 gaging station was operated for 17 years (October 1996-September 2012). Overall, data quantity and quality was good-excellent. Hourly surface-water and groundwater level monitoring began in 1995 (water year 1996). Both surface water and groundwater salinity measurements begin in 1996 and water temperature monitoring was started in 1999. Water level time-series measurement interval was changed to $15 \mathrm{~min}$ in 2003 and for salinity and temperature in 2008.

\begin{tabular}{|c|c|c|c|c|c|c|c|}
\hline \multirow{2}{*}{$\begin{array}{l}\text { Shark } 5 \\
\text { Period of record (hourly) }\end{array}$} & \multicolumn{3}{|c|}{ Surface water } & \multicolumn{3}{|c|}{ Groundwater } & \multirow[t]{2}{*}{ Rainfall } \\
\hline & Level & Salinity & Temperature & Level & Salinity & Temperature & \\
\hline Begin & 10/12/1995 & $4 / 11 / 1996$ & $5 / 20 / 1999$ & 10/12/1995 & $4 / 11 / 1996$ & 5/20/1999 & $9 / 29 / 2000$ \\
\hline End & 2/4/2003 & $3 / 18 / 2008$ & 3/18/2008 & $2 / 4 / 2003$ & 3/18/2008 & 3/18/2008 & 9/26/2012 \\
\hline \multicolumn{8}{|l|}{ Period of record (15 min) } \\
\hline Begin & 2/5/2003 & $3 / 19 / 2008$ & $3 / 19 / 2008$ & $2 / 5 / 2003$ & $3 / 19 / 2008$ & $3 / 19 / 2008$ & \\
\hline End & $9 / 26 / 2012$ & $9 / 26 / 2012$ & $9 / 26 / 2012$ & 9/26/2012 & $9 / 26 / 2012$ & 9/26/2012 & \\
\hline $\begin{array}{l}\text { Successful collection of } \\
\text { data ( } \% \text { of days during } \\
\text { POR). }\end{array}$ & 91 & 81 & 82 & 90 & 81 & 82 & 94 \\
\hline
\end{tabular}

SH5 data quality was good. Surface water salinity data collection was diminished due to equipment failure. Water pumping to sample salinity was used for 5 years with modest success, but was discontinued because of excessive maintenance and equipment failure. Gaging station platform was rebuilt in January 2003 and new monitoring equipment was installed. Hurricane Katrina (August 25, 2005) and Hurricane Wilma (October 24, 2005) wind and water damage to equipment and some data loss; and in addition, this gaging station had unusual and periodic animal damage to gaging station sensors, wiring and PV system that contributed to months of data loss over 5-6 years. SH5 instantaneous water data are available at South Florida Hydrologic Database, http://sofia.usgs.gov/exchange/sfl_hydro_data/location.html\#brdlandmargin. 
Big Sable Creek (BSC) Description

Latitude: $\quad 25^{\circ} 15^{\prime} 58.16^{\prime \prime}$

Longitude: $\quad-81^{\circ} 09^{\prime} 44.16^{\prime \prime}$

UTM Easting Zone 17N: 483661.15000

UTM Northing Zone 17N: 2794429.18000

Gaging Station Operational: July 26, 2001

Gaging Station Status: Transferred to NPS-Everglades on October 1, 2012

Gaging Station Location

Gaging station is located in a tidal mudflat at end of right fork of Big Sable Creek and adjacent to mangrove forest, $0.4 \mathrm{~km}$ east of Gulf of Mexico, Everglades National Park. Accessed by boat.

\section{History}

The gaging station consists of a surface water stilling well is a 12-in. diameter CMP pipe set in mud sediment (1 ft) to creek bottom. Gaging station was built on October 16, 2000, and was operational by July 26, 2001. Hurricane Wilma (October 24,. 2005) flood damage ruined monitoring equipment. Replacement equipment was installed on August 3, 2006. Gaging station platform was reconstructed August 20, 2009, with a stainless steel frame $0.08 \mathrm{ft}$ higher than previous monitoring platform with new monitoring equipment installed.

\section{Gaging Station Design}

Data logger, battery, and monitoring instruments are housed within an aluminum housing box on top of a wooden platform (rebuilt with stainless steel) supported by four steel pipes. Surface-water level, surface-water specific conductance; surface-water temperature; and rainfall were monitored. Gaging station was operated by a photovoltaic power system. Radio telemetry was initially used and later GOES satellite transmission was used for daily data transfer.

$\underline{\text { References and Benchmarks }}$

Measurement point (MP) is the aluminum base of the instrument housing on the gaging station platform. A local benchmark is a 3-in. aluminum cap set on a 5/8-in. rebar driven to refusal within a 3-in. PVC pipe filled with concrete approximately $80 \mathrm{ft}$ south of gaging station on a small mangrove island. Vertical (NAVD 88) and horizontal (NAD 83) references were determined by precise differential GPS survey by USGS in 2002 (OPUS solution, GEOID 99).

\begin{tabular}{|c|c|c|c|c|c|}
\hline Big Sable Creek & Aluminum platform base & 3-in. aluminum cap & \multicolumn{3}{|c|}{ Ground surface (Creek) } \\
\hline $\begin{array}{l}\text { Reference elevations } \\
\text { (ft, NAVD 88) }\end{array}$ & $\begin{array}{c}\text { Measurement point } \\
4.83\end{array}$ & $\begin{array}{c}\text { Local benchmark } \\
1.38\end{array}$ & Average & $\begin{array}{l}\text { Maximum } \\
\text { n/a }\end{array}$ & $\begin{array}{c}\text { Minimum } \\
\text { n/a }\end{array}$ \\
\hline
\end{tabular}




\section{Big Sable Creek (BSC) Data}

BSC River gaging station was operated for 11.25 years (July 2001-September 2012). Overall, data quality was good-excellent. In 2001, 15-minute surface-water level measurements and hourly salinity, temperature, and rainfall were started. Temperature and salinity time-series measurement interval was changed to $15 \mathrm{~min}$ in 2007.

\begin{tabular}{lcccc}
\hline Big Sable Creek & \multicolumn{3}{c}{ Surface water } & Rainfall \\
\hline Period of record (hourly) & Level & Salinity & Temperature & \\
Begin & & $7 / 26 / 2001$ & $7 / 26 / 2001$ & $8 / 10 / 2001$ \\
End & & $4 / 17 / 2007$ & $4 / 17 / 2007$ & $9 / 30 / 2012$ \\
Period of record (15 min) & & & & \\
Begin & $7 / 26 / 2001$ & $4 / 18 / 2007$ & $4 / 18 / 2007$ & \\
End & $9 / 30 / 2012$ & $9 / 30 / 2012$ & $9 / 30 / 2012$ & \\
Successful collection of data & 86 & 84 & 84 & 92 \\
(\% of days during POR). & & & & \\
\hline
\end{tabular}

BSC data quality was good. Note: The gaging station had no groundwater well and only monitored river stage parameters. Hurricane Katrina (August 25, 2005) and Hurricane Wilma (October 24, 2005) flooding and high winds caused catastrophic equipment failure and a 10-month loss of gaging station monitoring. New monitoring equipment was added in 2006 (post-Wilma) and the platform was rebuilt with stainless steel frame in August 2009. BSC instantaneous water data are available at South Florida Hydrologic Database, http://sofia.usgs.gov/exchange/sfl_hydro_data/location.html\#brdlandmargin. 


\section{Acknowledgments}

Project funds provided since 2006 by the U.S. Army Corps of Engineers, Memorandum of Agreement and Interagency Agreement W912EP-03, Comprehensive Everglades Restoration Plan (CERP), Monitoring and Assessment Plan (MAP). Thanks to G. Ronnie Best and the Priority Ecosystem Science Program and Pamela Tellis of the Everglades Depth Estimation Network (EDEN). USGS staff salaries are supported through the USGS Southeast Ecological Science Center (Kenneth G. Rice, director). Special thanks to Bryan McCloskey and Heather Henkel for their invaluable assistance to incorporate the data into the SOFIA Hydrologic Database. The field work in Everglades National Park was carried out under NPS permit number EVER-2012-SCI-0009 (or previous NPS permits). Special thanks to NPS employees Kevin Kotun, Roy Sonenshein, Damon Rondeau, Raymond Snow, Erik Stabenau, Robert Johnson, and Everglades National Park superintendent, Dan Kimball.

Thanks to the National Park Service Global Climate Change Study, the National Biological Survey, and U.S. Geological Survey Global Climate Change program. Special thanks to William Nuttle, Bernard J. Cosby, Robert Johnson, Hal Wanless, Michael Robblee, William Robertson Jr., Michael Soukup, James Snyder, and William Loftus for their initial study proposal. There are too numerous staff and volunteers to list all, but special acknowledgement to Christa Walker, Kevin Whelan, Fara Ilami, Greg Ward, Trish Lavin, Stephanie Beeler, Tim Montfort, Eric Agterberg, Matt Seiler, Stephanie Cleaves, Suzanne Cwahla, and all the international interns (especially the Netherlanders).

\section{References Cited}

Fennema, R.J., Neidrauer, C.J., Johnson, R.A., MacVicar, T.K., and Perkins, W.A., 1994, A computer model to simulate natural Everglades hydrology, in Davis, S.M., and Ogden, J.C., (eds.), Everglades - The ecosystem and its restoration: Delray Beach, Florida, St. Lucie Press, p. 249-290 Larsen, M.C., 2008, Water resources discipline policy on accepting furnished records: U.S. Geological Survey, WRD Discipline Policy Memorandum 2008.01.

Nuttle, W.K., and Cosby, B.J., 1993, Dynamics of groundwater, surface water and salinity related to the mangrove/marsh ecotone: Homestead, Florida, Everglades National Park, Year 1Annual Report, 12 p.

Odum, W.E., and McIvor, C.C., 1990, Mangroves, in Myers, R.L., and Ewel, J.J., (eds.), Ecosystems of Florida: Orlando, Florida, University of Central Florida Press, p. 517-548.

Schaffranek, R.W., Smith, T.J., III, and Holmes, C.W., 2001, An investigation of the interrelation of Everglades hydrology and Florida Bay dynamics to ecosystem processes in South Florida: U.S. Geological Survey Fact Sheet 49-01, 3 p.

Smith, T.J., III, 2004, Development of a long-term sampling network to monitor restoration success in the southwest coastal Everglades-Vegetation, hydrology, and sediments: U.S. Geological Survey Fact Sheet 2004-3015, 4 p.

Smith, T.J., III, Anderson, G.H., Tiling-Range, G., and Balentine, K.M., 2002, Dynamics of Land Margin Ecosystems: Historical Change, Hydrology, Vegetation, Sediment, and Climate, South Florida Information Access (SOFIA); U.S. Geological Survey at http://sofia.usgs.gov/projects/index.php?project_url=dyn_margin.

Smith, T.J., III, and Cahoon, D.R., 2003, Wetland sediment surface elevation in the Florida Everglades - response to surface water stage variation, in Proceedings, 5th International Symposium on Coastal Engineering and Science of Coastal Sediment Processes: Corpus Christi, Texas, East Meets West Productions. 
Soukup, M.A., Robertson Jr., W.B., Loftus, W.F., Robblee, M.B., and Snyder, J.R., 1990, Capabilities and interest statement - Global climate change research Southern Florida: Everglades National Park, $24 \mathrm{p}$.

United Nations Organization for Education, Science and Culture, 1985, The International System of Units (SI) in Oceanography: UNESCO Technical Paper In Marine Sciences, v. 45, 124 p.

U.S. Geological Survey, 2014, South Florida Information Access (SOFIA): U.S. Geological Survey South Florida hydrology database accessed March 6, 2014, at

http://sofia.usgs.gov/exchange/sfl_hydro_data/location.html\#brdlandmargin. 
Publishing support provided by the U.S. Geological Survey

Publishing Network, Tacoma Publishing Service Center

For more information concerning the research in this report, contact the Director, Florida Water Science Center

U.S. Geological Survey

1400 Colonial Blvd., Suite 70

Fort Myers, Florida 33907

http://fl.water.usgs.gov/ 


\section{हू}

곡

$\frac{2}{\frac{10}{4}}$

옹

ํㅡㅁ

울

弯

룰

产

$\Xi$

ํ. 임

क्ष

종

응

ก.

뭉

혹

家

ำ

Ð

罢

응

跑

끙

ํㅡㅇ

雨

蛋

悉

छे

Iิ

N

品 